\title{
GARSHUNI MALAYALAM: A WITNESS TO AN EARLY STAGE OF INDIAN CHRISTIAN LITERATURE
}

\author{
ISTVÁN PERCZEL ${ }^{1}$ \\ CENTRAL EUROPEAN UNIVERSITY
}

Garshuni (or Karshon) Malayalam is the common name in scholarly literature given to Malayalam texts written by the Saint Thomas Christians and by Western missionaries in the Malabar Coast, in South India in a specific script based on the Syriac alphabet with the additional use of originally eight—or nine-old Malayalam letters, as well as that of a number of secondary signs.

1 The article was written by István Perczel. However, whatever he knows about Garshuni Malayalam, he has learned it from the Rev. Dr. George Kurukkoor, a great Malayalee linguist, one of the last who can fluently read and understand Garshuni Malayalam. Several parts were checked by Dr. Ophira Gamliel of Bar Ilan University, Tel Aviv, who has unique expertise not only in Malayalam in general but also in Jewish Malayalam and Arabic Malayalam "religiolects." She also helped the author in preparing several of the translations contained in the present article. While the work of digitization has been supported and organized by the institutions acknowledged below in this text, special thanks should be expressed to Mar Aprem, Metropolitan of the Church of the East in India, who has been the greatest support of this project in the most difficult conditions, to Father Columba Stewart, the Executive Director of Hill Museum \& Manuscript Library, without whose sponsorship and practical support very little could have been done in India, and to Father Ignatius Payyappilly, Chief Archivist of the Ernakulam-Angamaly Archdiocese of the Syro-Malabar Church, who is the animating soul of the work for the preservation of the Saint Thomas Christian heritage. 
As there has never been any codified alphabet of Garshuni Malayalam, the number of the originally used additional letters has been expanded by even more letters and letter combinations. However, these latter characters are incorporated as foreign bodies in the script, not connected to the flow of the Syriac script.

\section{THE ORIGINS OF THE GARSHUNI MALAYALAM SCRIPT}

There are only a few studies and some sparse notes written on the topic of Garshuni Malayalam, and they contain only hypotheses about the origins and the age of this script. In his classical reference work on the South Indian scripts, ${ }^{2}$ A. C. BURNELL put forward the hypothesis that the additional characters are from the Arya ezhutthu, also called Modern Grantha, the ancestor of the modern Malayalam script, which was originally used for writing Sanskrit in South India and was introduced to write also Malayalam by the Malayalam poet Tunjettu Ezhutthachan, most likely in the second half of the seventeenth century. ${ }^{3}$

J. P. M. VAn DeR Ploeg studied MS Paris BN Syr 25, a composite Syriac manuscript containing also Garshuni Malayalam texts, which had been assembled sometime during the episcopacy in Malabar of Alexander de Campo (Mar Chandy Parampil: 16631687). As this was the earliest manuscript in which Van der Ploeg had found Garshuni texts, he concluded that the invention, or introduction, to the Malabar Coast of the Garshuni Malayalam

2 See A. C. Burnell, Elements of South-Indian Palaeography from the Fourth to the Seventeenth Century A.D., $2^{\text {nd }}$ ed. (London: Truebner - Mangalore: Stolz \& Hirner, 1878; reprint New Delhi - Madras: Asian Educational Services, 1994).

${ }^{3}$ Earlier this script was only used to write Sanskrit. On the literary activity of Tunjettu Ezhutthachan see Krishna Chaitanya, A History of Malayalam Literature (Hyderabad: Orient Longman, 1971, reprint 1995), pp. 82-88; Ezhutthachan is a caste name and means "schoolmaster." It was considered a low caste in Kerala. On the introduction of the Arya ęhuttu to write Malayalam by Ezhutthachan, see Burnell, op. cit. p. 35. Even Ezhutthachan's chronology is unclear. According to Krishna Chaitanya, Ezhutthachan lived in the sixteenth century but this seems to be a dating far too early. According to Burnell, Ezhutthachan lived in the second half of the seventeenth century. On the hypothesis that the additional characters of Garshuni Malayalam are borrowed from the Arya ęhuttu, see Burnell, p. 45. 
script could not be dated earlier than the second half of the seventeenth century. ${ }^{4}$ His hypothesis was that "this kind of garsini originated at the initiative or under the influence of the Maronites who were in Malabar in the $2^{\text {nd }}$ half of the $17^{\text {th }}$ century, and for whom garśuni (for the Syrians in the Middle East Arabic in Syriac characters) was not only quite normal but even felt as a quasinecessity." 5

The author of the most comprehensive introduction to date to Garshuni Malayalam, THOMAS KOONAMMAKKAL, ${ }^{6}$ doubts Van der Ploeg's conclusions. According to him so great was the loss of manuscripts due to the orders of the Synod of Diamper (1599 AD), which condemned the manuscripts of the Saint Thomas Christians, that the absence of manuscript evidence before the seventeenth century is not a conclusive argument for dating this script so late. ${ }^{7}$ Thomas Koonamakkal also thinks, although he admits that he cannot cite any compelling evidence for this, that Garshuni Malayalam must have existed already in the pre-Diamper period. ${ }^{8}$ The basis for this speculation is the existence of bilingual Syriac-Garshuni Malayalam dictionaries, as well as Syriac grammars written in Garshuni Malayalam, although the extant manuscripts are of later date.

In a chapter in a recent volume edited by Johannes Den Heier, Andrea Schmidt, and Tamar Pataridze, dedicated to the phenomenon of allography including also garshunography FATHER JOHNS ABRAHAM KONAT refers to a hitherto unpublished Ph.D. thesis, written by V. B. MARKOSE in Malayalam and defended in 2009 at the University of Calicut. ${ }^{9}$ According to Markose, Garshuni

${ }^{4}$ For the description of BN Syriac 25 see J. P. M. van der Ploeg, OP, The Christians of St. Thomas in South India and Their Syriac Manuscripts (Rome/ Bangalore: Center for Indian and Inter-Religious Studies/Dharmaram Publications, 1983), pp. 231-244.

${ }^{5}$ Van der Ploeg, op. cit., p. 244. A similar note can be found Ibid., 30.

6 Rev. Dr. Thomas Koonammakkal [Koonammakkal Thoma Kathanar], "An Introduction to Malayalam Karshon," The Harp 15 (2002): 99-106.

${ }^{7}$ Koonammakkal, op.cit., p. 101.

${ }^{8}$ Koonammakkal, op.cit., p. 102.

9 V. P. Markose, Karshoni Oru Bhahasastra Vilayithural. Thesis submitted to the University of Calicut for the Degree of Doctor of Philosophy, 2009, cited by J. A. Konat, "Malayalam Karshon - An Example of Cultural Exchange," in J. Den Heijer, A. Schmidt, T. Pataridze (eds.), 
Malayalam was in use in Kerala from the $17^{\text {th }}$ to the $19^{\text {th }}$ century. ${ }^{10}$ However, he also refers to the Synod of Diamper as the principal cause of the destruction of ancient Christian literature, saying that because of this destruction we cannot tell how far beyond the Synod of Diamper Garshuni Malayalam had been in use. Markose thinks that, most likely, this script was developed in the interaction of the Kerala Christians with their West Asian mother Church.

However, over and against the view that Diamper would have destroyed Garshuni Malayalam manuscripts, one may note that the canons of the Diamper Synod are extant; so, we can establish with great accuracy the list of the books condemned to be burnt. Most of them were well known Syriac theological works, as Jean-Baptiste Chabot has established. ${ }^{11}$ There is no indication that the Synod of Diamper would have condemned any literature written in Malayalam.

Father Konat also refers to SCARIA ZACHARIAH's introduction to the Malayalam text of the Synod of Diamper (1599), where Zachariah writes that the original Malayalam text of the canons, which the Malayalee participants in the Synod had to sign, was written in Garshuni. ${ }^{12}$ This should be the case, since all three Malayalam manuscripts of the Acts kept in the Vatican and also the text published by Scaria Zacharia include the following note:

It was ordered by the Archbishop in virtue of holy obedience and under pain of excommunication that no one called to the Synod should leave without signing the $<$ Acts of the $>$ Synod, written in Malayashma and

Scripts Beyond Borders: A Survey of Allographic Traditions in the EuroMediterranean World / Publications de l'Institut Orientaliste de Louvain; 62/ (Louvain-la-Neuve_Leuven: UCL Institute Orientaliste_Peeters, 2013). I thank Andrea Schmidt for sharing the manuscript of this important study with me. As it is not yet published, I cannot give the precise page numbers. All references to the thesis of V. P. Markose are from Father Konat's article.

${ }^{10}$ See the references in Konat, op. cit.

11 J.-B. Chabot, "L'autodafé des livres syriaques du Malabar," Florilegium Melchior de Voguë (Paris: Imprimerie Nationale, 1909), 613-623.

12 Scaria Zacharia (ed.), Udayampērburh SuNahadōsiNDe KäNōNakal (Acts and Decrees of the Synod of Diamper) (Palai: Indian Institute of Christian Studies, 1995), p. 57. 
Garshuni. ${ }^{13}$ The $<$ Acts of the $>$ Synod were written in the Malayalam language and characters, known to everybody and, after all, the <Acts of the $>$ Synod were signed. ${ }^{14}$

This text is a precious external witness, perhaps the earliest, to the sixteenth-century use of Garshuni Malayalam. It also gives room to some musing on the question of what it means by "Malayashma and Garshuni"? JONAS THALIATH translates Malayashma as "Malayalam,"15 but Scaria Zacharia is right when he notes that Malayashma is one of the old Malayalam scripts. ${ }^{16}$ More precisely, Malayashma is just another name for the script also called Thekken Malayanma, an old Malayalam script mostly used in southern Kerala. So it seems that there were two copies prepared for signature at the Synod, one in the Malayashma (Thekken Malayanma) script, probably on palm leaves and one in Garshuni, on paper. All this seems to indicate that the Garshuni way of writing Malayalam

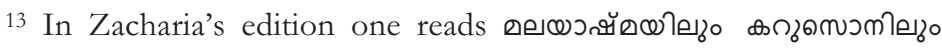

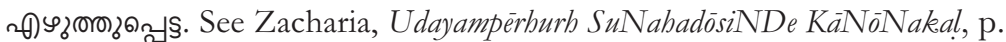
245.

14 Biblioteca Vaticana: 1. Fondo Vaticano Indiano MS 18, fol. 81; 2. Fondo Borgiano Indiano, MS 3, fol. 157; Ibid., MS 21, fol. 134, translated and cited in Jonas Thaliath, The Synod of Diamper, OCA 152 (Rome: Pontificium Institutum Orientalium Studiorum, 1958, reprinted at Bangalore: Dharmaram Vidya Kshetram, 1999), p. 176: the same text is translated in the context of the 19th canon of the Seventh session by Thaliath on p. 186, I have changed Thaliath's translation. This text corresponds approximately to the text published by Scaria Zacharia, $o p$. cit., p. 245.

15 "From this it looks as if the original idea was to prepare the decrees in Garshuni as well as Malayalam. But actually only the Malayalam text seems to have been prepared to be signed by all at the end of the Synod" (J. Thaliath, The Synod of Diamper, p. 176). This conclusion is based on Decree 25 of Action IX of the Synod, which ordered that the original of the Acts signed by all the participants was to be deposited at the archives of the Vaipicotta Seminary of the Jesuits and also on a note in the same decree, according to which the original signed by the participants was in the "Malabar language" (em lingoa Malavar, see António de Gouvea, Jornada do Arcebispo de Goa Dom Frey Aleixo de Menezes Primaz da India Oriental, Religioso da Orden de S. Agostino (Coimbra: Officina de Diogo Gomez, 1606), fol. 56v and 58r): see Thaliath, op. cit. p. 175.

${ }^{16}$ Scaria Zacharia, op. cit., p. 245, note 160. 
was common knowledge and a widespread practice among the Saint Thomas Christian elite in the late sixteenth century. As we will see, a study of the extant Garshuni Malayalam manuscripts confirms these conclusions.

If so, we can posit 1599 as a first terminus ante quem of the Garshuni Malayalam script and state with certitude that this script was already known in the $16^{\text {th }}$ century. ${ }^{17}$ Fr. Konat also notes that Garshuni Malayalam remained in use still in the $20^{\text {th }}$ century, as his personal library contains manuscripts written in this script by his grandfather, the famous Malpan Mattai Konat, who passed away in 1927.18

The results of the SRITE PROJECT ${ }^{19}$ for digitizing and cataloguing the manuscript heritage of the Saint Thomas Christians, carried out by the Association for the Preservation of the Saint Thomas Christian Heritage (APSTCH) and supported by Hill Museum \& Manuscript Library, Tübingen University, and the German Research Foundation as well as Central European University, now permit a more precise, although still inconclusive, assessment of the origins and nature of Garshuni Malayalam. In fact, in the framework of this project we have digitized a great number of manuscripts either containing Garshuni Malayalam texts together with Syriac texts, or containing uniquely Garshuni Malayalam texts.

The first impression is that Garshuni Malayalam texts constitute an entire, hitherto unexplored treasure-house of Eastern Christian literature, with a great number of translations and original creations.

Second, over against Burnell's statement cited above, out of the nine characters of Garshuni Malayalam additional to the Syriac alphabet, only one was borrowed from the Arya ezhutthu, while the other eight - the original additions - came from one of the old Malayalam alphabets, perhaps Malayashma/Tekken-Malayanma [used in Travancore], rather than Kolezhutthu [used in Malabar and Kochi]. ${ }^{20}$ From this fact, combined with the date of the earliest

${ }^{17} \mathrm{~J}$. A. Konat, op. cit.

${ }^{18} \mathrm{~J}$. A. Konat, op. cit.

${ }_{19}$ On the SRITĒ project see www.srite.de.

${ }^{20}$ From among the old Malayalam alphabets Burnell only mentions the Vatterbuttu script in his book. A more detailed study of the alphabets used in Kerala is L. A. Ravi Varma's PräciNa kèrbalha lipikalh (Ancient 
evidence of Garshuni Malayalam texts, one can draw the conclusion that Garshuni Malayalam antedates the introduction of the Arya ezhutthu (modern Grantha) by Kunjettu Ezhuttachan in the second half of the seventeenth century. It is also true that, at least in later manuscripts, one also finds letters borrowed from the Arya ezhutthu, first, and most commonly, $(S h a)$ and also later, ${ }^{21}$ s (bha) and $ஜ(j a)^{22}$ as well as, in a unique manuscript, the modern Malayalam ligature for $j n y i: 23$

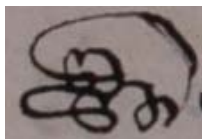

However, the fact that these letters are not integrated into the ductus of the script but always stand alone indicates that they were borrowed at a later stage and do not belong to the original character set of the script.

Third, the hypothesis that the Maronites would have introduced this kind of script can be ruled out by all that has been said above: Garshuni Malayalam was used in Malabar long before the Maronites' arrival in Malabar. Also, Van der Ploeg's hypothesis is untenable because Garshuni Malayalam is exclusively written in East Syriac characters, even by those scribes who otherwise use the West Syriac alphabet for writing Syriac. Moreover, as the Appendix shows, the choice of the Syriac letters for indicating the Malayalam phonemes is conditioned by the East Syriac pronunciation of Classical Syriac. Some sparse texts written in West Syriac Garshuni Malayalam would appear only by the end of the nineteenth century.

Finally, fourth, it seems that this script, called locally Suriyani Malayalam, that is, "Syriac Malayalam," is to be considered in parallel with Aräbi Malayalam, that is, "Arabic Malayalam," meaning

Kerala Scripts; in Malayalam, with very detailed tables) (Trivandrum: The Malayalam Improvement Committee, 1938, reprint: Thrissur: Kerala Sahitya Akademi, 1971). Ravi Varma's book does not contain the Garshuni Malayalam alphabet.

${ }^{21}$ See, for example, Ernakulam Major Archbishop's House Syr MS 7, ff. 515r-517r.

22 See also Thomas Koonammakkal, "An Introduction to Malayalam Karshon," p. 104 (without concrete reference to the manuscript). See also in the Appendix, under $\$ C .1-2$.

23 Mannanam Syr 49, fol. 31r-32r. See also in the Appendix, under \$C. 3 . 
Malayalam written in Arabic characters, practiced by the Muslim communities of Kerala. Similarly to Aräbi Malayälam, Suriyani Malayalam seems to be an indigenous script, developed by the priestly elite of the Saint Thomas Christians, although the earliest known texts written in this script were produced either by the missionaries, or because of their influence. Yet, it is to be noted that, while Garshuni Malayalam is a mixed script, Aräbi Malayalam, just like other Indian Muslim scripts such as Urdu, is an adaptation of the Arabic script to Malayalam, without the incorporation of Malayalam letters.

\section{THE EARLIEST INTERNAL EVIDENCE FOR THE USE OF GARSHUNI MALAYALAM}

The oldest texts containing Garshuni Malayalam characters that I have seen, with one exception dating to the mid-sixteenth century, are found in seventeenth-century manuscripts, but they also attest that Garshuni Malayalam must have been in use already in the sixteenth century. It is to be noted that old manuscripts written in Kerala are extremely rare; only one, Vatican Syr 22-dated 1301is older than the sixteenth century. ${ }^{24}$ All the other old Kerala manuscripts are from the sixteenth century.

The first occurrences of Garshuni Malayalam that I know can be found in Syriac texts transcribing place names of the Malabar Coast in this script. In the colophon of Trivandrum, Mar Ivanios College MS Syr 1, a codex of the four Gospels copied in 1563, the place name Kollam is written according to the rules of Garshuni Malayalam, with a line under the lamad indicating reduplication (בحفحر). However, while the manuscript had been copied in 1563, apparently the folio with the colophon (fol. 180) had been damaged and was replaced by a copy made in the eighteenth century. One can only guess that the original could already contain the Garshuni spelling of Kollam, but this is not compelling evidence.

${ }^{24}$ See Van der Ploeg, op. cit., p. 187-189. 


\section{Garshuni place names in Syriac letters of missionaries, late $16^{\text {th }}$-early $17^{\text {th }}$ century}

Another early occurrence of Garshuni Malayalam is in MS Syr 46 of the collection of St Joseph's CMI Monastery in Mannanam, ${ }^{25}$ a miscellaneous manuscript datable to the early $17^{\text {th }}$ century, which contains a partly dated collection of letters, exchanged in Syriac between missionaries and local priests. The earliest letter in the collection can be tentatively dated - on the basis of the events, to which it refers - to 1580-1585, while the second letter is fairly certainly datable to 1597 . Other letters bear precise dates, respectively 1603, 1604, 1607 and 1608. Apparently, the letters testify to an early state of Garshuni Malayalam transcription of place names, which would change in later times. Thus, Kochi is transcribed as Kuksin (حصحمى), 26 although its later Garshuni transcription would be حفيَب (27) ${ }^{27}$ the underlining under the shin indicating the consonant $c a($ (لد). In Letters 1 and 8, Pāravur/ Parur

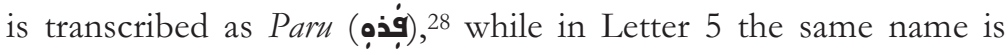

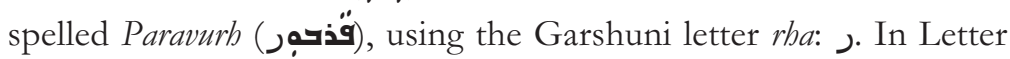
2, dated 1597 and written by one of the missionaries (presumably Francisco Roz, who, together with Antonio Toscano, was one of the two accomplished Syriacists among the missionaries ${ }^{29}$,

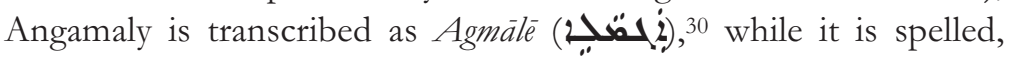
much more correctly, as Angamäle (2كبلم) in Letter 5.31 Later, it

25 The numbering of the manuscripts in this entry follows the checklists of the SRITE project. The original shelfmark of Mannanam MS Syr 46 is 090-252-S. The manuscript was first briefly mentioned by Emmanuel Thelly in: "Syriac Manuscripts in Mannanam Library," Symposium Syriacum VII: Journal of Eastern Christian Studies 56/1-4 (2004): 257-270, here: p. 268, Literary Works 3.

${ }^{26}$ Letter 1, Mannanam Syr MS 46, fol. 192ra, and also Letter 8, Ibid. fol. 193rb.

27 As one finds the placename in Mannanam Syr MS 49, fol 3r, a MS datable to the early 19 th century.

${ }^{28}$ Letter 1, Mannanam Syr MS 46, fol. 192ra, and also Letter 8, Ibid. fol. 193rb.

${ }^{29}$ Later Roz was to become the first European Metropolitan Bishop of Angamaly/Cranganore (1602-1627).

${ }^{30}$ Letter 2, Mannanam Syr MS 46, fol. 192ra.

${ }^{31}$ Letter 5. Mannanam Syr MS 46, fol. 193ra. 


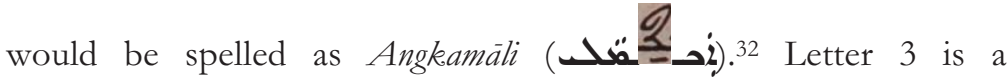
certificate, by Francisco Roz, about the ordination of a certain Presbyter Paulos who can celebrate anywhere in the Malabar Diocese and in India. In his own notes appended to the letter, Presbyter Paulos has indicated the circumstances of the certificate. Accordingly, it was written in Kothamangalam, spelled here as

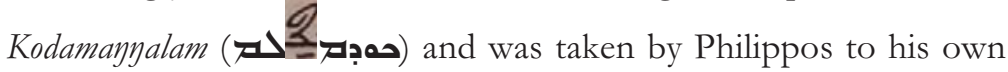
birthplace called Chenotta (كنف (2)), being another name for Chennamangalam. ${ }^{33}$ Here both the use of the duplicate letter $(n g g, \eta \eta)$ and the use of the Syriac shin for transcribing Malayalam $c a$ are testimonies to the usage of the Garshuni signs and rules. Letter 4 was written, by a missionary, from Mulanturuty, spelled here as

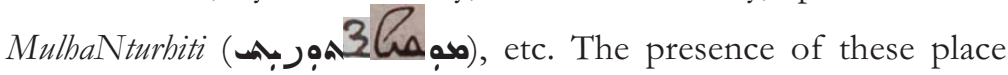
names, written in Garshuni Malayalam, and the fact that they do not display any unified system of transcription, indicate that the scribes copied faithfully the details found in the letters and that, so, this script was used by the original letters, dating to the early seventeenth century. The same manuscript contains homiliesmost likely written by the missionaries - for the feast days, written in Garshuni Malayalam. These homilies can be dated to the late sixteenth or perhaps early seventeenth century.

\section{SOME TYPES OF IMPORTANT GARSHUNI MALAYALAM MANUSCRIPTS}

\subsection{Rubrics in Catholic liturgical texts, $17^{\text {th }}$ century}

The paper of a splendid liturgical manuscript in the collection of the Trivandrum Major Archbishop's House (Trivandrum MS Syr 2) bears in its watermark the number 646, which could indicate its date. While this is just a hypothesis, this dating corresponds to that

32 As one finds the placename in Mannanam Syr MS 49, fol 2v. The $k a \bar{p}$ before the underlined $\eta$ indicates that $\eta$ is reduplicated.

${ }^{33}$ Letter 3, Mannanam Syr MS 46, fol. 192va. 
proposed by J. P. M. Van der Ploeg ${ }^{34}$ and also to my personal examination of the paper and the script. So, we can propose 1646 $\mathrm{AD}$ as a possible terminus a quo for the manuscript and, presumably, it was written not long after that date. It is a Catholic liturgical book, containing a lectionary, the text of the anaphora of the Twelve Apostles according to its revision at Diamper, and other liturgical texts conforming to the Latinized rite imposed at Diamper. Interestingly, in this manuscript, rubrics-that is the interjected prescriptions for the celebrants-are in Syriac, with the exception of the prescriptions for Good Friday (ff. 26r-36r) and the blessing of the curtains of the sanctuary (ff. 209v-210r), where they are written in Garshuni Malayalam. So these two texts constitute an early example for the pattern that Syriac prayers are accompanied by rubrics in Garshuni Malayalam. This practice must have been introduced to facilitate the celebration for those priests who were reading Syriac but did not understand the language easily. Most likely the fact that the service of Good Friday demands very complicated movements inspired the addition of Malayalam rubrics to the Syriac text. This phenomenon seems to explain the sentence from the Acts of the Synod of Diamper cited above: "The <Acts of the $>$ Synod were written in the Malayalam language and characters, known to everybody." In fact, as the liturgical texts of the Indian Church were in Syriac, every priest was familiar with reading the Syriac script, while not all of them understood Syriac. To write and read Malayalam in these characters, once the additional signs were there, would have been easy. When the rubrics were in Garshuni Malayalam, even those priests who did not know Syriac were able to celebrate the services. Although the missionaries widely used this script, it seems to me that the only reason for this was that this was the most common way, or one of the most common ways, of writing Malayalam in the Christian community.

Trivandrum MS Syr 2 can be fruitfully examined in parallel to Mannanam MS Syr 63. This manuscript contains early seventeenthcentury material, while the manuscript itself may be later, perhaps from the eighteenth century. The main part of Mannanam MS Syr 63 contains the original poetry of Kadavil Chandy Kattanar, an

${ }^{34}$ J. P. M. van der Ploeg, O. P., The Christians of St. Thomas in South India and their Syriac Manuscripts (Rome and Bangalore: Center for Indian and Inter-Religious Studies-Dharmaram Publications, 1983), p. 88. 
Indian poet writing in Syriac. ${ }^{35}$ In the same manuscript one also finds a version of the mass of Francisco Roz, translated from Latin and intended to replace the East Syriac liturgy of Addai and Mari and of the Twelve Apostles, used in the East Syriac/Chaldean Church and, so also, in Malabar. The text is written so that the prayers are in Syriac, while the rubrics indicating what the participants should do are in Garshuni Malayalam. These rubrics are very extensive and include lengthy explanations. ${ }^{36}$ The text is entitled "Order of the Offering of the Sacraments." It is incomplete and breaks after the recitation of the Creed. On fol. $174 \mathrm{r}-\mathrm{v}$ there is a short colophon in Garshuni Malayalam, which says, among other things: "This new text of the mysteries (i.e. sacraments) was ordered by Mar Franciscus Metropolitan."

This incomplete text of the new Latinized mass is followed by a Breviary (Hudra) for the main feasts, of very interesting character

35 On Kadavil Chandy Kattanar, see P. J. Thomas, Malayala Sabityavum Christyanikalum (Malayalam Literature and the Christians) (Athirampuzha: St. Mary's Press, 1935; second edition with additions by Scaria Zacharia: Kottayam: DC Books, 1989), pp. 143-144; E. M. Philip, The Indian Church of St. Thomas (first published: Kottayam: E. P. Mathew Edavazhikal, 1908; second edition by Kuriakose Corepiscopa Moolayil, Cheeranchira, Changanessery: Mor Adai Study Centre, 2002), pp. 135137; Curien Chorepiscopa Kaniamparampil, The Syrian Orthodox Church in India and Its Apostolic Faith (Detroit, MI: Rev. Philips Gnanasikhamony, 1989), pp. 90-92; the discovery of one of his poems was announced by Emmanuel Thelly in: "Syriac Manuscripts in Mannanam Library," Journal of Eastern Christian Studies 56 (2004): 257-270, here 261 and 267; a letter by him, found at the digitization of the Thrissur Chaldean Syrian library, was published by A. Toepel in: "A Letter from Alexander Kadavil to the Congregation of St. Thomas at Edapally," in: D. Bumazhnov, E. Grypeou, T. Sailors and A. Toepel (ed), Bibel, Byzanz und Christlicher Orient: Festschrift für Stephen Gerö zur 65. Geburtstag (Leuven: Peeters, 2011), pp. 387-398; the discovery of Chandy's collected poems in Mannanam MS Syr 63 and 99 was announced by I. Perczel in: "Classical Syriac as a modern lingua franca in South India between 1600 and 2006," in: Modern Syriac Literature, ARAM Periodical 21 (2009): 289-321, here 304-307. A more comprehensive study on Kadavil Chandy's newly discovered œuvre by I. Perczel is forthcoming: "A Syriacist disciple of the Jesuits in 17th-century India: Alexander of the Port/Kadavil Chandy Kattanar" in Journal of the Canadian Society for Syriac Studies 14 (2014).

36 Mannanam MS Syr 65 (original shelfmark: 090-264-S), fol. 153v$174 \mathrm{v}$. 
(174v-216r). The hymns belong to the East Syriac cycle. They contain a revised version of the traditional prayers. In fact, after the creation of the Chaldean Church in union with Rome in 1551, several such versions were made. None of the corrections introduced was very thorough and, while some crucial passagessuch as the commemoration of the three Syriac and three Greek Doctors, that is, Mar Aprem, Mar Narsai and Mar Abraham, on the one hand, and Diodore of Tarsus, Theodore of Mopsuestia and Nestorius, on the other-were changed in various ways, the original Nestorian theology transpires through the hymns. So also in our text, which, instead of Ephrem, Narsai, and Abraham, lists Ephrem, Basil and Athanasius and, instead of Diodore, Theodore, and Nestorius, commemorates "Mar Aprem (once again), Mar Ignatius, and Mar Polygraphus, who were truly priests and teachers" (fol. 205v). However, it also contains such verses as the following:

For those who in their ignorance are going astray and in their quarrelsomeness are denying the humanity of our Saviour, who is the pride of the members of his family [that is, of the human beings] and the good cause of all the rational beings, let us pray that they may leave the schisms and divisions that the rebellious Great Adversary has brought upon them, so that they may approach the sweet argument of the true faith and that we may be preserved in pure heart and harmonious thought. Let all of us together, with the venerable priests, raise glorification and thanksgiving to the eternal Head of our nature who, in His grace, has converted us to the knowledge of the truth and has returned us from the scrutiny that is in the..., to whom belong our glorification and blessing to the end. Amen (fol. 214v-215r).

Here "the humanity of our Saviour" is indeed treated as a separate concrete entity. It (that is, he) is "the pride of his family and the good cause of all the rational beings," "the eternal Head of our nature;" apparently Jesus' humanity is considered here a pre-existent entity, being a kind of super-humanity, or idea of humanity.

Yet, this strong Nestorian/Chaldean flavour notwithstanding, the Hudra is apparently the one used in the Church of the New Faction (Putthankür), headed by the Mar Thoma Metropolitans and 
under the jurisdiction of the Syrian Orthodox Patriarch of Antioch. In fact, the commemoration formula reads as follows:

For our holy Fathers, Mar Ignatius so-and-so,
Catholicos Patriarch, the Head of the entire Church of
Christ, and Mar Thoma so-and-so, Metropolitan
Bishop, let us pray that they may be confirmed
according to the leadership of Moses and that they may
absolve according to the priesthood of Aaron, and that
they may receive the keys as Peter and that they may
hold fast in mercy in this world and that they may raise
the religion of the Most High! (fol. 202rv)

This is clearly the East Syriac, not to say explicitly Nestorian, commemoration, adapted to the Syrian Orthodox Patriarch, who is named according to the rank of the Catholicos Patriarch of Babylon. So, apparently, those who were using this mixture of East Syriac (Nestorian/Chaldean) and Roman Catholic liturgy, in fact belonged to the Mar Thoma faction under the jurisdiction of the Syrian Orthodox Patriarch of Antioch. Paradoxically, the aforementioned prayer for the conversion of those who, according to this view, qualify as "deniers of the humanity of our Saviour" concerns all the other faithful of the same patriarchate, whose confession of faith was miaphysite and who would not have agreed in any way with the theology of these services. In this Hudra, all the rubrics are in Syriac, not Malayalam.

The last item in the manuscript (on foll. 216v-217v) is an account, in Garshuni Malayalam, on the sufferings of Christ, giving perfect numbers for each type of humiliation that Jesus received. The language of the text is a mixture of Malayalam and Syriac. It is in Malayalam, but as it contains many numbers, the numbers are indicated in either Malayalam or Syriac. In the following translation the letters $\mathrm{M}$ and $\mathrm{S}$ indicate whether a numerical expression is in Malayalam or in Syriac:

O, Lord Christ, your beautiful eyes have shed sixty thousand two hundred $(M)$ drops of tears; you have bled ninety-seven thousand three hundred and five $(M)$ drops of blood and water. On your holy neck you were hit in the number of hundred and twenty times $(\mathrm{M})$; on your holy head (?) thirty times (M); on your holy mouth hundred and sixty times $(\mathrm{M})$; upon your holy face you were spit thirty two times $(\mathrm{M})$; on your holy back, three 
hundred and fifty times (M); on your holy chest, fortythree times (M); on your holy head, eighty-five times (M); in your holy leg, you received kicks hundred and seventy times (M); on your holy side, thirty-eight times (M); on your shoulders and arms sixty-two times (S); at your waist twenty-eight times $(\mathrm{S})$; on your back thirtytwo times (S); on your belly forty times; you were pushed to the ground thirteen times $(\mathrm{S})$; your hair was plucked three hundred ... < times $>$ (S) ...

It is difficult to decide whether the manuscript is simply a miscellany uniting disparate texts or a combined testimony to the complex liturgical and spiritual traditions of a definite group. A parallel manuscript, namely Piramadam MS Syr 28, the personal service book of Mar Thoma VI (Dionysius I), the Metropolitan of the Mar Thoma faction between 1765 and 1809, suggests that the mixture of liturgical traditions found in the Mannanam manuscript was the rule rather than the exception, and thus, the community that used both the Nestorian/Chaldean Hudra and the Latin/Syriac mass of Francisco Roz is precisely the one that commemorated the Syrian Orthodox Patriarch of Antioch and the Mar Thoma Metropolitan. If so, it is noteworthy that the (rather simple) rubrics in the Hudra are in Syriac and only the complicated rubrics of Roz's mass are in Garshuni Malayalam just as, in Trivandrum MS Syr 2, only the rubrics of the service of Good Friday and those of the blessing of the curtains of the sanctuary are in Malayalam. Apparently, these new liturgical texts needed at their introduction clearer explanations than the usual ones that had been celebrated by generations of priests and, thus, it was safer to introduce these explanations in the mother tongue of the celebrants.

Finally, as to the odd note on Christ's passion, I doubt that this text would have any European source. Even the visions of Anna Katherina Emmerick are not that detailed and, certainly, not as far as numbers are concerned. Rather, it seems that this text is the combination of two imaginative traditions: on the one hand, of the Jesuit tradition of spiritual exercises, that is, meditating on Christ's passion and, on the other hand, of the Indian way of narrating stories with precise numbers. The way it combines Malayalam and Syriac is also an interesting testimony to a now extinct SyroMalayalam dialect that must have been once the dialect spoken by Christians, before they switched to standard Malayalam. This extinct Syro-Malayalam dialect should be placed in parallel with the 
Arabi Malayalam dialect spoken by Muslims and the Jewish Malayalam dialect spoken by the Kerala Jews up to the present day. ${ }^{37}$ Below, I will return to this question.

If all the material of the manuscript testifies to the liturgical and spiritual tradition of one and the same community under the Mar Thoma Church, then, through this material, we can gain insight into the complex identity of this group, which may have accommodated Roz's new mass together with the revised Nestorian liturgy and the humanist poetry, written in Syriac, of Kadavil Chandy Kattanar, while jurisdictionally belonging to the Syrian Orthodox Church. In this way, through its very syncretism, this Church remained fundamentally Indian.

\subsection{Garshuni Malayalam Acts of the Synod of Angamaly (1583) and of the Synod of Diamper (1599)}

Bangalore Dharmaram College MS Syr 32 (= MS GarMal 2) contains a copy of the Garshuni Malayalam text of the Acts of the Synod of Diamper, held in 1599, a well-known turning point in the history of the Church of Malankara. I am undecided as to the date of the manuscript. The original Malayalam Acts, upon which all the participants put their signatures, have been lost. According to Jonas Thaliath, there are three Malayalam manuscript copies of the decrees kept in the Vatican Library, namely Fondo Vaticano Indiano MS 18 and Fondo Borgiano Indiano MSS 3 and 21.38 In 1952 K. N. Daniel published the Malayalam Acts using five Indian manuscript copies. ${ }^{39}$ Another edition was made by Scaria Zacharia in 1994.40 For this edition Dr. Zacharia used, among others, a manuscript

37 Due to the paradoxes of twentieth-century history, the Jewish Malayalam dialect is, by now, mostly spoken in certain villages in Israel. See below, note 85 .

38 See J. Thaliath, The Synod of Diamper, pp. 177-192. See also Andrews Thazhath, The Juridical Sources of the Syro-Malabar Church (A Historico-Juridical Study) (Vadavathoor, Kottayam: Paurastya Vidyāpịtham, Pontifical Oriental Institute of Religious Studies, 1987), p. 135.

${ }^{39}$ K.N. Daniel, Udayampèrhurh SuNahadōsiNDe KäNōNakal (Canons of the Synod of Diamper) (Thiruvalla: C. L. S., 1952). I have not had access to this publication.

40 Scaria Zacharia, Udayampērhurh SuNahadōsiNDe KäNōNakal 1599 (Canons of the Synod of Diamper) (Idamattam, Kerala: Indian Institute of Christian Studies, 1994). 
from St Joseph's CMI Monastery in Mannanam, which is, according to our checklist, Mannanam MS Mal 1, dated 1768.41 The Bangalore manuscript was not used for these editions. It was found at an unidentified place and "rescued" by the great Church historian, the late Fr. Mathias Mundadan CMI, who placed it in the library of the Dharmaram College. He was studying it and wanted to publish his results, but was prevented from doing so by his death in 2012. He considered this manuscript the most important early canonical source, preserved in India, for the history of the Indian Church. ${ }^{42}$

The analysis that follows here was made on the basis of the following material: 1. the Bangalore manuscript; 2. the Portuguese text published by António Gouvea; ${ }^{43}$ 3. Scaria Zachariah's edition; 4. the Mannanam manuscript of the Malayalam Acts, 5. Jonas Thaliath's detailed analysis of the Vatican manuscripts and of the only Portuguese manuscript Thaliath was able to find, namely Rome, MS Fondo Gesuitico 721.VI.1, brought to Rome by Alberto Laerzio, the Jesuit Procurator of India Oriental in 1599. In what follows I will refer to items 3 and 4 as well as the Malayalam manuscripts of the Vatican as the 'Arya ezhutthu manuscripts.'

Jonas Thaliath, having made a detailed collation of the Vatican manuscripts with the Portuguese Acts, has shown that the Malayalam text is both shorter than and different from the Portuguese, which, according to all the testimonies contains a good number of additions and corrections introduced by Menezes after the Synod. He also has shown that the procedure of adding new material to the original Acts continued until a, quite propagandistic,

41 The original call number is 262.91 MAN S 2847.

42 Oral information received from Fr. Ignatius Payyappilly, whom I thank most warmly for all his contributions.

43 The Portuguese acts were published in Portugal as an appendix to António de Gouvea, Jornada do Arcebispo de Goa Dom Frey Aleixo de Menezes Primaz da India Oriental, Religioso da Orden de S. Agostino (Coimbra : Officina de Diogo Gomez, 1606), comprehending 62 folios. J. H. da Cunha Rivara republished the text on the basis of the Coimbra edition in J. H. da Cunha Rivara (ed.), Archivo Portuguez-Oriental, Fasciculo 40 que contem os Concilios de Goa e o Synodo de Diamper (Nova-Goa: Imprensa Nacional, 1862, reprint: New Delhi: Asian Educational Services, 1992), p. 281-528 (see Rivara's Prologue to the edition), which should mean that the State Archives of Goa do not contain a copy of the Acts — an odd fact in itself. 
edition was made by Archbishop Aleixo de Menezes and published by António Gouvea in 1606, as Laerzio's manuscript, although fundamentally corresponding to Gouvea's text, is also somewhat shorter. Thaliath has concluded that the Malayalam text of the Vatican manuscripts, although showing signs of a further redaction after the Synod, is closer to the original Acts than the Portuguese text published, after heavy redactional activity, by Aleixo de Menezes. ${ }^{44}$ As to the text of the Indian Arya ezhutthu manuscripts, it is closer to the Portuguese and differs from the Vatican manuscripts. The Garshuni Malayalam text of the Bangalore manuscript, while being closer to the Vatican manuscripts than to the Indian Arya ezbutthu manuscripts, also differs in many respects from these and constitutes one further step toward the original of the Malayalam Acts, and perhaps even corresponds to that original.

In the Bangalore manuscript, the text of the Acts of Diamper begins on fol. 14 of the manuscript, in a rather insignificant manner, with these words:

The holy synod in the year 1599 of Christ, on June 26, with altogether 813 participants, among which, without the fourth, fifth and sixth order of the serving ranks (shemashummare), ${ }^{45} 163$ priests, while many people also came from Udayamperoor and there were also present many Portuguese people, both priests and laymen. ... has decided (ceydhu)."

This is information that, in the other texts, one finds only at the end of the Acts. ${ }^{46}$ However, the Portuguese text gives the number 153 for the priests, while the Vatican manuscripts agree with the Bangalore manuscript that there were 163 priests.

According to António Gouvea, before the opening of the Synod, Archbishop Aleixo de Menezes had written the Acts of the

44 See the analysis of Jonas Thaliath, The Synod of Diamper, p. 179-90.

45 See the corresponding Portuguese text in Gouvea, fol 58r and Archivo Portuguez-Oriental, Fasciculo 4o, p. 513. The "fourth, fifth and sixth order of the deacons" corresponds to "deacons, subdeacons and the other shamashas (serving ranks)" (Diaconos, Subdiaconos, e mais Chamazes) in the Portuguese. The same expression "fourth, fifth and sixth order" is also the expression used by the Vatican manuscript in the part corresponding to the Portuguese: MSS Vat. Ind. 18, fol. 85v, Borg. Ind. 3, fol. 166, Borg. Ind. 21, fol. $141 \mathrm{v}$. Borg. Ind. 3 gives 814 as the number of those present. See J. Thaliath, The Synod of Diamper, p. 187, n. 29.

${ }^{46}$ See the previous footnote. 
Synod in the Fort of Cranganore and invited Malabaree priests of the Latin rite to translate them under the supervision of the Jesuit Francisco Roz. ${ }^{47}$ The introduction to the Arya ezhutthu text of the Malayalam Acts is more precise: it attributes the translation to the Priest Jacob, vicar of the church at Pallurutthi, together with Francisco Roz and Antonio Toscano. ${ }^{48}$

In the Bangalore manuscript, the Acts of Diamper are preceded by the text of the Malayalam canons (called in the text qanuna) of another synod, which had seven sessions. The text begins with the sixteenth canon of the sixth session, the beginning of the manuscript having been lost. Most likely, this other synod preceded in time the Synod of Diamper, so I wonder whether the manuscript contains the canons of the first Synod of Angamaly, held in 1583 under Mar Abraham, which, in fact, was the first regulation according to Catholic canon law and customs adopted for the Angamaly Diocese of the Saint Thomas Christians. ${ }^{49}$ However, there is a difficulty. The Third Provincial Council of Goa, held in 1585, in Decree 6 of its Third Session, mentions 28 chapters that Mar Abraham had accepted at a diocesan synod, which have been considered and approved by the Goan Council.

According to Andrews Thazhath, the Goan Council refers to the diocesan Synod of Angamaly.50 The Acts of the unnamed synod in the Bangalore manuscript contain many more canons: 31 at the sixth session and 19 at the seventh. Here I would hypothesise that, perhaps, only some of the canons accepted at Angamaly, judged as relevant from the Portuguese perspective, were translated and submitted for approval to the Goan Council. Interestingly, in a Syriac manuscript (Mannanam MS Syr 46, foll.

47 See Book I, chapter XVII in Gouvea, Jornada, fol. 57ra and 58ra. For an English translation see Pius Malekandathil (ed), Jornada of Dom Alexis de Menezes: A Portuguese Account of the Sixteenth Century Malabar (Kochi: LRC Publications, 2003), p. 230-31 and 235.

48 S. Zacharia, Udayampērhurh SuNahadōsiNDe KäNōNakal, p. 109-110, corresponding to Mannanam MS Mal 1, fol. 3rv.

49 On this synod see, Thazhath, op. cit., p. 130-31 and also Joseph Thekkedath, History of Christianity in India, vol. 2: From the Middle of the Sixteenth Century to the End of the Seventeenth Century (1542-1700) (Bangalore: Church History Association of India, 1988), p. 52.

50 See the text of the Council in Archivo Portuguez-Oriental, Fasciculo 4o, p. 148. See also Thazhath, op. cit., p. 129. 
206r-209v) I found a selection of the canons of the Third Goan Council, which have been translated into Syriac. Instead of 28 canons, this text speaks about "all that has been written in the Synod of Angamaly and of Diamper and has been taken here (that is, to Goa)" (ibid. fol. 208v). If the canons in the Bangalore manuscript indeed belong to the diocesan Synod of Angamaly, then, we have recovered at least part of the Acts of this synod, which had been believed to have been lost. ${ }^{51} \mathrm{My}$ hypothesis that the canons of the preceding synod are those of Mar Abraham's Synod of Angamaly conforms to the opinion of the discoverer and rescuer of the manuscript, Fr. Mathias Mundadan. ${ }^{52}$

In the manuscript, the Acts of Diamper follow the acts of this preceding synod without interruption. The end of the manuscript is missing, so that the text is interrupted in the middle of the eighth canon of the sixth session, erroneously called the seventh, corresponding to the ninth canon of the eighth session in the Portuguese Acts. ${ }^{53}$

In the Bangalore manuscript, the convocation letter of Aleixo de Menezes is missing, just as in all the Malayalam texts. ${ }^{54}$ However, the Acts of the first session on the first day, which are there in all the other testimonies, namely the Portuguese Acts and

${ }^{51}$ See Thazhath, op. cit., p. 131 and Thekkedath, op. cit., p. 52.

52 Oral information from Fr Ignatius Payyappilly.

${ }^{53}$ Dharmaram College MS Syr 32, fol. 43v, corresponding to p. 46163 in Archivo Portuguez-Oriental and to fol. 46rv in Gouvea's edition. In J. Thaliath's counting, this is the sixth session of the Malayalam Acts, as the sixth session is missing, see Thaliath's table of correspondences, op. cit., p. 226. In Scaria Zacharia's edition, Udayampērburh SuNahadōsiNDe KäNōNakal, this corresponds to p. 211. The last legible word in the Bangalore manuscript is viricikannyayer. "the month of Vricikam"November-December (Vrishcikanyayar: வðणीகளைळr in the Arya ezhuttu manuscripts.

54 Archivo Portuguez-Oriental, p. 283-88, Gouvea, fol. 1r-2r. See also J. Thaliath, The Synod of Diamper, p. 180. The following comparison of the structures of the three versions (the Portuguese text, the Arya ezhuttu manuscripts and the Bangalore Garshuni manuscript) is based on the comparative tables in J. Thaliath, The Synod of Diamper, p. 219-228 and the detailed table of contents in S. Zacharia, Udayampērhurh SuNahadōsiNDe KāNōNakal, p. 100-105. Details were checked in the text of Zacharia's edition and the structure of the Bangalore manuscript was compared to these. 
the Arya ezhutthu manuscripts, are also missing from the Bangalore manuscript. Instead, there is a long introduction, longer than that of the second session in the Portuguese text, including the first decree of the second session, followed by the confession of faith prescribed for all the priests and faithful to recite. This corresponds to the second session in the Portuguese Acts and to the second "consultation" (yogavicāaim) of the first session (mauthuvā/mauthva $\bar{a}^{-55}$ ) in the Arya ę̧ butthu manuscripts. ${ }^{56}$ It is noteworthy that, apparently, the text of the Bangalore manuscript uses "session" (mauthuva) and "consultation" (yogavicäräm) as synonyms, both—a Syriac and a Malayalam word-corresponding to acção in the Portuguese, while the Arya ezhutthu manuscripts separate the meanings of the two and use "consultation" as a sub-section of "session."

After this begins Session 2, which roughly corresponds to Session 3 of the Portuguese Acts and to Session 2 of the Arya ezhutthu manuscripts. Just like in the Arya ezhutthu manuscripts, it contains 20 canons, the first 5 of which are called "decree" (kalppana), while the remaining 15 are called "canon" (qanuna). Unlike this, the Portuguese Acts contain 23 decrees, all of which are called decreto. Decrees 10, 17, and 19 of the Portuguese Acts are missing from all these Malayalam texts. After this, in the Portuguese Acts, Session 4 follows, its subject being Baptism and Confirmation, while the Arya ezbutthu manuscripts call the next section the "Consultation 2" of Session 2. This section in the Arya ezhutthu manuscripts treats Baptism, Confirmation, and the Eucharist together, thus including the subject of Session 5 of the Portuguese Acts, too. However, what follows in the Bangalore manuscript is "Consultation 3" concerning these three sacraments. While the Portuguese Acts contain 20 canons on Baptism and 3 on Confirmation, the text of the Arya ezhutthu manuscripts contains 13 canons on Baptism and 3 on Confirmation. In contradistinction to these two variants, the Bangalore manuscript contains only 7 canons on Baptism and 3 on Confirmation. Still, to this Session 3

${ }^{55}$ Mauthuva is a Syro-Malayalam word derived from the Syriac mant$b \bar{a}$ : "session." It is spelled so in the Bangalore Garshuni manuscript. The Arya ezhuttu manuscripts edited by Zacharia have mauthvā, which, apparently, corresponds to a later, slightly changed pronunciation. However, the change is minimal, as the $u(0)$ sound in Garshuni Malayalam often indicates a semi-vowel (shwa).

${ }^{56}$ Gouvea, fol. 2v-4r, Archivo Portuguez-Oriental, p. 288-95. 
belongs the Eucharist, with 9 canons in the Portuguese Acts and 8 in the Malayalam Acts, including the Arya ezhutthu and the Bangalore manuscripts. Session 4 of the Malayalam Acts is about the sacraments of Holy Mass, Penance and Extreme Unction. In the Portuguese Acts there are 15 canons on Holy Mass, over against which there are 9 canons in the Malayalam version, 15 on penance, as opposed to 13 in the Malayalam versions and 3 canons in all the versions on Extreme Unction. Session 5 in the Malayalam manuscripts, on the Holy Orders, corresponds to the first part of Session 7 in the Portuguese Acts, with 17 canons on the Orders as opposed to 23 in the Portuguese. Apparently, to this same Session 5 in the Malayalam versions, corresponding to the second part of Session 7 in the Portuguese, belong also the canons on Matrimony, 16 in number in all the versions. Session 6 is on the duties of the lay Christians in the churches and their settlements, corresponding to Session 8 in the Portuguese Acts. However, this is called erroneously Session 7 in the Bangalore and the Arya ezbutthu manuscripts, as the Arya ezhutthu manuscripts contain another Session 7 corresponding to Session 9 in the Portuguese Acts. It is with the $8^{\text {th }}$ canon of this Session 6 (erroneously called seventh) that the text is interrupted in the Bangalore manuscript. ${ }^{57}$

It is also noteworthy that, according to all the Malayalam witnesses, including the Arya ezhutthu manuscripts, the Synod took place at the church dedicated to the Lady Mary (Marth Maryam) at Udayamperoor while, according to the Portuguese Acts, the Synod was convened in the church dedicated to All the Saints. According to the Malayalam Decree 19 of Session 6, Consultation 6 (corresponding to Decree 25 of Session 8 according to the Portuguese Acts), as well as according to Gouvea, the church had been originally dedicated to Mar Shahpur and Mar Aphraat, the two East Syrian bishops who came to Malabar in the ninth century, and was rededicated to All the Saints by Archbishop Menezes after the Synod. ${ }^{58}$ Also, the Synod of Diamper, Session 8, Decree 25

57 See above, note 53 .

58 Gouvea, Jornada, Book 2, ch. 2, fol. 75v. The Portuguese transcription for these Persian names is Marxabrò e Marprobd and, in Decree 25 of Session 8, Marxobro e Marprobd. The Malayalam transcription in the corresponding Decree 19 of Session 6, Consultation 6, is Mar Chavor and Mar Aprotthu, which is closer to the original Persian form of these names: see S. Zacharia, Udayampērhurh SuNahadōsiNDe KāNōNakal, p. 220. 
according to the Portuguese Acts, Session 6, Consultation 6, Decree 19 according to the Arya ę̧ hutthu manuscripts, had decreed that churches dedicated to these two saints, deemed Nestorian, should be rededicated to All the Saints and that the feast of these churches should be celebrated on the $1^{\text {st }}$ of November. ${ }^{59}$ I would guess that the dedication to the Lady Mary testifies to an intermediate stage when the old dedication to Mar Shahpur and Mar Aphraat was not any more accepted but the rededication to All the Saints had not yet happened. ${ }^{60}$

A preliminary linguistic comparison of the Bangalore text to Zacharia's edition also shows a number of differences. These indicate that the Garshuni version of the Acts was written in a dialect that, on the one hand, contained archaic forms of standard Malayalam words and, on the other hand, was full of Syriacisms. Contrary to this, the Arya ezbutthu manuscripts, represented in Zacharia's edition, contain more standard Malayalam words and the Syriacisms are sometimes either eliminated from the language, or, perhaps, misunderstood. So, for example, the feast of the Transfiguration on $6^{\text {th }}$ of the month of August (Cinganyayer) is indicated in the Bangalore manuscript as Gébyänē $\langle h\rangle d$-Märan enna

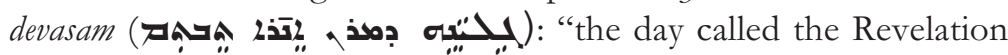
of our Lord," or "the day of the Revelation of our Lord, so-called." "Called," or "so-called" (enna) is added here, because Gélyanēe $<b>d$ Märan is a Syriac expression. In the Arya ezhutthu Acts this has

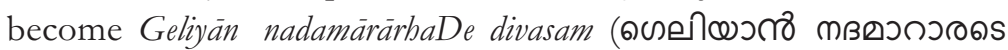
вीऽmo), apparently reproducing a popular, Malayalamized version of the name of the feast, so that it is clear that the scribe did not understand the meaning of the Syriac name. ${ }^{61}$ Such changes from a

59 Gouvea, fol. 49v, Archivo Portuguez-Oriental, p. 476-77, S. Zacharia, Udayampērburh SuNahadōsiNDe KāNōNakal, p. 220.

${ }^{60}$ A different explanation is given by J. Thaliath, The Synod of Diamper, p. 189 , n. 30 .

${ }^{61} \mathrm{I}$ am giving here the expression as it stands in the Arya ezhuttu manuscript Mannanam MS Mal 1, f. 50v. The spelling is incorrect: even in this form the expression should be written as Geliyanna damärärhaDe

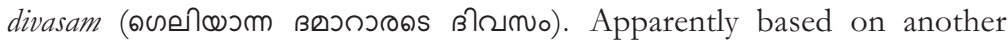
Arya ezhuttu manuscript, Scaria Zachariah gives in his edition the form

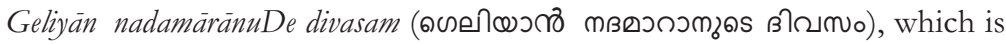
closer to the original Syriac form of the feast but testifies to the same 
clearer Suriyāni Malayalam language to a more standard and popular Malayalam form also testify to the fact that, over against the Bangalore Garshuni manuscript, the Arya ezbutthu manuscripts are reproducing a secondary form of the Malayalam Acts of Diamper.

To resume, the Garshuni Malayalam text of the Bangalore manuscript, which has not become part of the studies concerning the Synod of Diamper, is of the type of the Arya ezbutthu manuscripts but differs in substantial elements from these. The present preliminary study confirms the judgment of the late Fr. Mathias Mundadan who had rescued the manuscript for us that this is the manuscript closest to the original Malayalam Acts of the Synod. Whether or not it contains the original text prepared by Malabaree priests under the direction of Francisco Roz remains to be demonstrated.

\subsection{Apocryphal Acts of the Apostles from the $16^{\text {th }}$ century}

MS Mal Gar 1 of Fr. George Kurukkoor's personal manuscript collection contains apocryphal Acts of the Apostles and Lives of early saints in Malayalam, including the Acts of Thomas, all translated from Latin. The texts are written in Garshuni script and testify to a heavily Syriacized state of the Malayalam language. Interestingly, a partly overlapping collection was also found in a nineteenth-century palm-leaf manuscript, written in Arya ez̧hutthu.62 A comparative study of the two versions shows that the palm-leaf variant contains fewer Syriac elements and its language is much more heavily Sanskritized. ${ }^{63}$ Using comparative material I was able to date the original version of the palm-leaf redaction to the period between 1665 and $1700 .{ }^{64}$

error of separating the Syro-Malayalam word Geliyanna (Udayamperrburh SuNahadōsiNDe KāNōNakal, p. 211).

62 Ernakulam Major Archbishop's House PL 1. I have analyzed the content of this MS in "Language of Religion, Language of the People, Languages of the Documents: The Legendary History of the Saint Thomas Christians of Kerala," in: Language of Religion - Language of the People: Judaism, Medieval Christianity and Islam, ed. Ernst Bremer, Jörg Jarnut, Michael Richter and David Wasserstein, (Munich: Wilhelm Fink Verlag, 2006), pp. 387-428, here: 417-421.

63 Particularly, I have compared the two redactions of the Acts of Thomas, translated from Latin.

${ }^{64}$ See "Language of Religion, Language of the People..." p. 419. 
However, the creation of the apocrypha should be placed to an earlier period, namely the first decades of the seventeenth century, after the Synod of Diamper, which, in its Decree 14 of Session 3 according to the Portuguese Acts, corresponding to Canon 13 of Session 2 in the Malayalam Acts, condemned a set of Syriac apocryphal Acts of the Apostles and many Lives of the Saints of the Church of the East. I suppose that our new set of apocryphal Acts and Lives of the Saints, translated from Latin, must have been created to replace this earlier collection, deemed heretical.

\subsection{Erasmian-style polemical dialogues in Malayalam, written by a missionary in the $18^{\text {th }}$ century}

A famous manuscript written in Garshuni Malayalam is Mannanam MS Syr 74 (=MS GarMal 2), which contains polemical works against the Jews and the "Jacobites," as it calls the members of the New Faction (putthankur) who seceded from the Roman Catholic Old Faction (pazhayakurr) and gradually joined the Antiochian Syrian Orthodox Patriarchate. It contains two dialogues and a treatise. The text is in Malayalam written in Garshuni script; the titles are normally in Malayalam, incidentally in Syriac. The community of St Joseph's Monastery believes that both dialogues are the work of Kariattil Joseph, the Archbishop of India of tragic fate who had studied at the Seminary of the Congregation of the Propagation of the Faith in Rome and, in 1778, embarked upon a famous trip to Europe together with Parammakkal Thomas Kattanar, and came back as Archbishop of the Saint Thomas Christians, only to die in Goa in $1786^{65}$ - this is also written on the cover of the book. A study on this text was published by Father Emmanuel Thelliyil under the title Catechism of Dr. Joseph Kariatti;66

65 See Placid J. Podipara, CMI (ed. and trans.), The Varthamanappusthakam: An account of the history of the Malabar Church between the years 1773 and 1786 with special emphasis on the events connected with the journey from Malabar to Rome via Lisbon and back undertaken by Malpan Mar Joseph Cariattil and Cathanar Thomman Parammakkal, written by Cathanar Thomman Parammakkal, Orientalia Christiana Analecta 190 (Rome: Pontificium Institutum Orientalium Studiorum, 1971), reprint: Dr. Thomas Kalayil, CMI (ed.), Collected Works of Rev. Dr. Placid J. Podipara, C.M.I., I-III (Mannanam: Sanjos Publications, 2007), vol. I, p. 433-614.

${ }^{66}$ Emmanuel Thelliyil, "Catechism of Dr. Joseph Kariatti," in The Harp 2 (1989), pp. 45-48. 
also, an edition of the second dialogue in modern Malayalam transcription along with an introduction was published by E. Attel. ${ }^{67}$ The view that the author of the entire book is Kariattil Joseph is repeated by J. A. Konat in his recent summary on Garshuni Malayalam. ${ }^{68}$ However, the hypothesis of Kariattil Joseph's authorship is based on an interjected colophon on f. 81r, which says the following:

In the year of Christ thousand seven hundred sixty-eight, Kollam era nine hundred forty three, the twenty-fifth day in the month of Edhavam (June) according to the new counting, the son of Jacob and Hanna, Putthenpurakkel Jacob Kattanar from Kanjirapally, when he was residing in the rectory of the Small Church in Kuravilangad, received this book with the so-called Dialogue from Ayippu Matthew Joseph Kattanar of Alangad and copied this copy.

From this colophon we are justified only to draw the conclusion that the first dialogue was copied after 1768, based upon an older manuscript that Putthenpurakkel Jacob Kattanar had acquired in 1768, apparently from Kariattil Joseph who, indeed, must be identical with Ayippu Matthew Joseph Kattanar from Alangad, as his doctoral certificate from the School of the Congregation of the Propagation of Faith is issued to "Cariatus Curiainppe Indus ex Mangate una ex urbibus regiis Malabarorum." 69

The manuscript contains two polemical dialogues and a polemical treatise. The first dialogue consists of five chapters, all of them called separately dialogues. The whole text begins on fol. 2r. There is no general title for the work, the first title that we read is in Syriac, in red ink, and it says: Dialoga qadmàya, that is, "First Dialogue." After that, it lists, in an interesting combination of SyroMalayalam, the dramatis personae. These are Rabbi Yáqov, Yüdha, Käporä, Krestiyañā and Ishmailayya, that is, Rabbi Jacob, a Jew, a Pagan — that is, Hindu — a Christian, and a Muslim. I would say that this line uses uniquely Syriac, were it not for the form Yüdha, which is the Malayalam word for Jew, the Syriac being Yudāya

${ }^{67}$ E. Attel, Vedatharkanthinte Bhashasasthrabhoomika, Trivandrum, 2010, cited by J. A. Konat, "Malayalam Karshon - An Example of Cultural Exchange," n. 24.

68 by J. A. Konat, op. cit.

${ }^{69}$ Mannanam MS Lat 1, f. 8v. 
The first dialogue, or chapter, in Syro-Malayalam Saba, bears the title: "On the fact that the Messiah comes suddenly to this world" (fol. 2r): Mashïhā i-lokatthungel vaNNadhinDè akshaNham ayadhu.70 (fol. 2r) It begins outside the Synagogue of Paravur, where a Christian, a Muslim, also called Jonakan, that is, "Greek," meaning a western merchant, an Arab, and a Hindu are standing together and the Hindu, also called Kapora, that is, pagan, and a Malayalan, that is, a Malayalee, sees an inscription on the upper front of the synagogue, which, to him, looks like an image, and asks Rabbi Yaqqov about its meaning. As the text of the inscription is from Psalm 137:5-6: "If I forget you, Jerusalem, my right hand will be forgotten; if I do not consider you, my tongue will lose its speech" (the translation here follows the Malayalam text), the Rabbi explains it from the Jewish tradition and, then, first a Jew, then the Muslim and, finally, the Christian joins the conversation, so that the discussion unfolds over the prophetic words of David and the role of Jerusalem in salvation history.

For the rest, the whole dialogue follows the rules of the genre of polemical dialogue, elaborated by Erasmus of Rotterdam and much practiced in $16^{\text {th }}-17^{\text {th }}$ century European Catholic literature, the whole text being saturated with humanist erudition including a knowledge of Hebrew. So the Psalms of David are called by the Jewish Rabbi Sepher Theblim (fol. 2r, sic!), and not Mazmōrè according to the Syrian Christian tradition, and the author translates the Psalmic verses directly from Hebrew into Malayalam according to their meaning without any regard to the other versions. The dialogue ends with the Hindu postponing the discussion to the next day and this remains the pattern for every dialogue, which promises the continuation at the next meeting.

The second dialogue bears a Syriac title: "On the divinity and

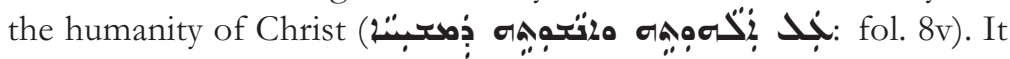
occurs one day later and is initiated by the Christian who asks the Rabbi whether, according to the Jewish tradition, the Messiah is only man, or is man and God at the same time. The Rabbi affirms that the Messiah is only man but challenges the Christian to prove

${ }^{70}$ In modern Malayalam script the transcription would be: $₫(\curvearrowright า \Omega)$

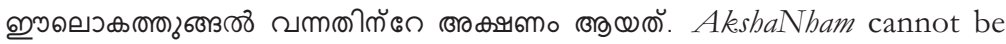
clearly seen as it is under a tape stuck to the text but can be inferred to from what is seen. 
the opposite from the Jewish Scriptures if he is able to. Then, the discussion unfolds along these lines. The scriptural texts on which the Christian starts to demonstrate that Christ is not only man but also God are Isaiah 42 and 9:5-6, followed by a commanding array of supporting Biblical citations (Psalms, Kings etc.) The Christian, as a good debater, tries to use for his argument the Jewish tradition, which he apparently knows quite well. He cites the opinions of the Rabbis commenting upon Isaiah 9:5-6, such as a certain Rabbi Yehoshua, who had written that "peace" (shlammä: a Syro-Malayalam word) in Is 9:5 is the Messiah's name and also a letter of Rabbi Moses the Egyptian (obviously Maimonides) to other rabbis, and "Rabbi Abenaziah" (Abraham Ibn Ezra?) who, according to him, said in his commentary on Isaiah that the Messiah was God (fol. 9rv). After this he cites the testimony of what he calls the "Chaldean Targum," being the translation of the Syriac Peshitta version $(9 \mathrm{v})$. Then the Jew and the Hindu and finally also the Muslim enter the debate, which continues in the same learned manner. In this, the Muslim makes a strong argument in favour of the absolute oneness of God, which leads to the subject of the third dialogue, which is about the Holy Trinity.

The third dialogue bears the title, in Syriac, "On the glorious

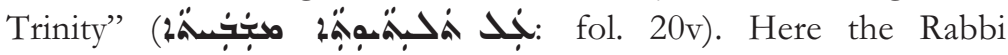
challenges the Christian concerning the oneness of God contradicted by the Christian claim that God is Father, Son, and Holy Spirit. In his answer the Christian cites first Gen 1:26: "Let us make man according ot our image and likeness" as well as Gen 11:7: "come, let us confound their language," traditionally used in Christian apologetics as testimonies to the Trinity. To this, the Jew responds with the traditional Jewish exegesis as the plural referring here to the angels and the debate continues thereupon. Here, to a logical question asked by the Hindu, the Christian answers with an argument taken from Aristotle (fol. 25v).

The fourth and the longest dialogue is titled, in Malayalam, "When did the Messiah come?" (fol. 31r). It begins with a sharp debate between the Christian and the Rabbi on this question and occupies 40 folios.

Finally the fifth dialogue bears the title, in Malayalam, "Whether Yehoshua Ha-Nossri is proven to be the Messiah" (fol. 71r). The dialogue ends with the Rabbi accepting the Christian argument. 
The second dialogue bears the title: "This is a refutation (thudamanam: "beating" from thudikkuka?) of the Jacobites" (YaqöbāyēkeārhèrbuDè thuDamānam äguNNadhu idhu) (fol. 86v)—a dialogue between a Pazhayakür (a faithful of the Old Allegiance, that is, a Catholic) and a Putthankēr (a faithful of the New Allegiance, that is, a Syrian Orthodox). The dialogue is full of erudite detail on Church history. It begins with the condemnation at the Council of Chalcedon of Nestorius, Archbishop of Constantinople, because he introduced two persons in Christ and called the Holy Virgin Mother of Christ instead of Mother of God; it mentions Eutyches and Dioscorus, etc.

Finally, the third text is a treatise titled in Malayalam Sakala nyāyà nammà mumbilatthè tharbkekam idbu (fol. 126r). I would understand this title as something like: "This is the argument on the entire law before us," but I am not certain about the meaning. Nyāam normally means "logic," "reasoning" but, according to Ophira Gamliel, in the Jewish Malayalam dialect its meaning is law, halakhah, and this might be the case in this Christian Malayalam dialect, too. Be this as it may, this is a systematic treatise, apparently written against the Jacobites, on the Catholic dogma, with an emphasis on the Papal primacy and much historical material partly from more ancient times and partly going into modern Indian Church history. At the end of the historical part, a writing is mentioned, about which the text says the following: "In the year 1793, on the $7^{\text {th }}$ day of the month of Mithunam, at Varappuzha (Verapolly), our Metropolitan Joseph wrote this in the Punniyavalan church." As the whole manuscript has been written by one and the same hand, this note gives us 1793 as terminus post quem for its date of copying and shows that the colophon at the end of the first dialogue is not by the scribe of the present book but one taken over from its model. Also it shows that the author of the third text had belonged to the Latin diocese of Verapoly, under the Congregation for the Propagation of the Faith. These considerations permit us to address the question of the authorship of the three different texts included.

In the manuscript no author is mentioned. The first dialogue must have been written before 1768, the date of the interjected colophon. It is certain that an indirect model of the text had been in the possession of Malpan Kariattil Joseph when he was teaching at the Alangad Seminary, but this does not necessitate that he was 
also the author of the text. Rather, a study of the text seems to reveal that it must have been written by a European missionary of great erudition and very good intellectual capabilities, who had mastered the Malayalam language perfectly. The author makes a display of his knowledge of Hebrew and Syriac and shows remarkable humanist erudition. He is aware of the stakes when discussing with Jews, Hindus, and Muslims and uses a genre that was much used in the $16^{\text {th }}-18^{\text {th }}$ centuries, that of the polemical dialogue. He translates directly from Hebrew into Malayalam and knows quite well the Jewish exegetical tradition. It would be difficult to identify him beyond any reasonable doubt, but I would be tempted to place him hypothetically in the circles of Johann Ernst Hanxleden (1681-1732), called in Kerala Arnos Padhiri, a German Jesuit missionary of immense erudition, who arrived in Kerala in 1700, aged 19, and lived there until the year of his death. Arnos Padhiri learned Malayalam and Sanskrit from two Nambuthiri Brahmins in Pazhur (present Pazhuvil, 19 kms SouthWest from Thrissur) and also learned Syriac while staying in Kerala. He wrote one of the first Sanskrit grammars by a Western author, ${ }^{71}$ a Malayalam grammar, ${ }^{72}$ a Malayalam-Portuguese dictionary, ${ }^{73}$ and a

71 Hanxleden's Sanskrit grammar had been considered lost but recently, in 2010, Ton Van Haal discovered it in the library of the Carmelite monastery of San Silvestro at Monte Compatri (Lazio). The editio princeps of the work was published in 2013: Grammatica Grandonica : the Sanskrit Grammar of Johann Ernst Hanxleden S.J. (1681-1732) / introduced and ed. by Toon Van Hal \& Christophe Vielle, with a photographical reproduction of the original manuscript by Jean-Claude Muller (Potsdam : Universitätsverlag Potsdam, 2013, also available online at: http://opus.kobv.de/ubp/volltexte/2013/6321/pdf/hanxleden_gram matica.pdf). The other two Sanskrit grammars are that of Heinrich Roth (1660-62) and Jean-Françis Pons (before 1732, see Ibid. Preface). Paulinus a Sancto Bartholomaeo's Sanskrit grammar published in 1790 seems to have been plagiarized upon Hanxleden's (Ibid. p. 13-15).

72 According to $\mathrm{Van} \mathrm{Hal}$ and Vielle, this grammar remains unpublished. However, on the basis of a manuscript kept at SOAS, London, Antony Joseph edited an anonymous Portuguese Arte Malavar as being Hanxleden's work. As both the first nominal paradigm and the general frame of this grammar correspond to the short description of the manuscript by Paulinus a Sancto Bartholomaeo (De manuscriptis codicibus indicis R. P. Joan. Ernesti Hanxleden epistola ad R. P. Alexium Mariam a S. Joseph Carmelitam Excalceatum, Vienna, 1799), Van Hal and Vielle think that 
Portuguese-Malayalam ${ }^{74}$ dictionary, and composed several poetic writings in Malayalam; ${ }^{75}$ his songs, such as the Putthan Panam about the life of Christ, are still sung by Christian families. Apparently, a full catalogue of Arnos Padhiri's Malayalam work is yet to be established. Here I would not go farther than to propose Arnos Padhiri as a potential author of the first dialogue.

I have not studied the second dialogue sufficiently to establish whether or not it is from the same author as the first or is only modelled upon it. Finally the third item, the treatise on Christian doctrine, must be from a different, later author, who must have been an erudite Indian Christian who lived around the end of the $18^{\text {th }}$ century.

\subsection{Syrian Orthodox texts}

Garshuni Malayalam was also used by the Syrian Orthodox missions to India, starting in the second half of the seventeenth century. Thus, Syrian Orthodox liturgical books can be found modelled upon the pattern of Roz's revised mass, that is, with the prayers of the Qurbono in Syriac and the rubrics in Garshuni Malayalam. There are also texts that are, in a way, the mirror image of this arrangement, namely Syrian Orthodox homilies (suwōode written in Garshuni Malayalam, with titles and rubrics in red ink in Syriac but also with Syriac elements inserted in them in black ink. Such are, for example, three homilies in a manuscript found at

this attribution might be correct. See Antony Joseph (ed.): Amnnōshŭ Päthiri, Malayäla vyäkaranam (Changanassery: Ranjima Publications, 1993). All this information is taken from Van Hal and Vielle, op. cit., p. 7-8.

73 S. Guptan Nair (ed.): Arṇnōosŭ Pāthiri, Vocabularium Malabarico Lusitanum - Malayälam pörccugišu nighanț (Trichur: Kerala Sahitya Akademi, 1988). Information from Van Hal and Vielle, op. cit., p. 7.

${ }^{74}$ The manuscript of the dictionary is at the library of the Coimbra University in Portugal and remains unpublished but is available online at: http://almamater.uc.pt/referencias.asp? $\mathrm{f}=\mathrm{BGUCD} \& \mathrm{i}=18080100 \& \mathrm{t}=\mathrm{ER}$ NESTO,\%20JOAO, \%20\%3F-1732. Information from $\mathrm{Van} \mathrm{Hal}$ and Vielle, op. cit., p. 7.

75 A critical edition of an (incomplete) collection of Hanxleden's Malayalam poetic works was published in 2002: N. Sam. Kuryāsŭ Kumpalakkuli and D. Benjamin (eds), Amnōsupätiriyute käryaninal: päthavum pathanavum (Kottayam: Current Books, 2002). Information from Van Hal and Vielle, op. cit., p. 6. 
Gethsemane Dayro in Piramadam, namely Piramadam MS Syr 11, which contains Jacobite polemical treatises, written in Syriac in East Syriac script. The manuscript was copied in India on a type of Italian paper that was in usage there in the late seventeenth, early eighteenth century. ${ }^{76}$ So I think that this book testifies to the reception of the first Syrian Orthodox missions, probably that of Mor Baselios Yaldo and Mor Iyovannis Hidayat Allah, who came to India in 1686.

The main body of the manuscript consists of Middle Eastern Syrian Orthodox polemical treatises collected for the sake of Indian usage. The first is an "Answer to the arguments of the Franks (that

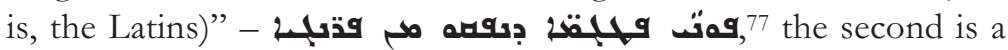
dialogue between a Syrian Christian and a Melkite on the part of the Trisagion Hymn, contentious between the Melkite and the miaphysite communities: "who hast been crucified for us." 78 After the well-known poem "O God, give learning to the one who loves learning...," against the Nestorians in which there is a proof of the orthodox confession and citations from their [the Nestorians'] teachers who are contradicting both the truth and themselves, in thirteen chapters." $" 80$

This anti-Nestorian treatise is interrupted at the beginning of the seventh chapter, after which come two entire homilies and a fragmentary one in Garshuni Malayalam, the first for the feast of Saint Thomas on July $3,{ }^{81}$ the second for the first day of the Fast of the Ninevites, ${ }^{82}$ and the third, of which only the beginning is extant, for the third day of the same fast. ${ }^{83}$ The end of the manuscript is missing.

76 This is my tentative dating upon the examination of the watermarks of the manuscript.

77 Piramadam MS Syr 11, fol. 1r-49r

78 The title is: "Other questions and answers to the arguments on 'who hast been crucified for us,' which is in the 'Holy God,' which we are saying when we pray." Ibid. fol. 50r-65r.

${ }^{79}$ Ibid. fol. 65v.

${ }^{80} \mathrm{Ibid}$. fol. 66r-85v.

81 Ibid. 88r-93r.

82 Ibid. 93 r-98r.

${ }^{83}$ Ibid. $98 \mathrm{rv}$. 
These homilies are written in a sort of mixture of Malayalam and Syriac. Not only the scriptural verses upon which the homily comments are in Syriac_by that time there was no Malayalam translation of the Bible-but there are also other insertions in Syriac; in fact, the preacher constantly switches from Syriac to Malayalam and back. So quoting the Syriac doctors (malpanmar), he says: "For this reason the Doctors are repeating: 'Great is the story of Thomas and greater than any word and understanding and it has become a cause for benefit for all the children of baptism." "For this reason...repeating" is in Malayalam but "Great is...children of baptism" is in Syriac, after which the Malayalam text continues. ${ }^{84}$ Who could be the audience of such homilies? Apparently quite erudite Christians, who were accustomed to listen to scriptural readings in Syriac, were also able to understand Syriac outside the scriptural texts but were happy to listen to the preaching in their mother tongue, while it was also simpler for the preacher to speak in Malayalam, while filling his speech with Syriac clusters. My impression is that we are encountering here, as also in general in the Garshuni Malayalam literature, a specific dialect of Malayalam, still characteristic of the Christian community in the sixteentheighteenth century, which we could call the Suriyāni Malayalam dialect in parallel with the Arabi Malayalam, spoken up to the present day by the Muslim community of Kerala, and with Jewish Malayalam, spoken by the Kerala Jewish community. The latter community lives now in Israel, having settled in a number of villages, such as Mesillat Zion near Jerusalem. Their dialect was the subject of a language documentation project initiated under the auspices of the Ben Zvi Institute in Jerusalem upon a local initiative of community members in the Jerusalem area and Dr. Ophira Gamliel from the Hebrew University, during which an oral archive was created to document the fast fading language variation of Jewish Malayalam, still spoken in Israel. ${ }^{85}$ Contrary to Arabi

${ }^{84}$ Ibid. $88 \mathrm{v}-89$ r.

${ }^{85}$ Some publications emerging from this project are: Scaria Zacharia and Ophira Gamliel, Kärkulali - Yefefia - Gorgeous: Jewish Malayalam Womens' Songs (Jerusalem: Ben-Zvi Institute, 2005) and-this publication contains ca. $20 \%$ of the collected corpus Jewish Malayalam women's songs_-it is not provided with a critical apparatus; Ophira Gamliel, Jewish Malayalam Women's Songs, Ph.D. dissertation defended at the Hebrew University in April 2009, available online: http://shemer.mslib.huji.ac.il/ 
Malayalam and Jewish Malayalam, the Suriyāni Malayalam dialect does not exist any more as a spoken language. Apparently, due to societal changes and its on-going integration into the newly forming Kerala society, in the nineteenth century the Christian community switched to standard (and heavily Sanskritized) Malayalam.

\subsection{Historical documents preserved in Garshuni Malayalam}

Garshuni Malayalam script was also used to transcribe and preserve documents that were judged important and, thus, worthy of preservation. Often these documents are letters, originally written on palm-leaves (öla), whose original has been lost but which were copied in paper manuscripts in order to be preserved for posterity. Most likely on the original ola-s, the text was written in one of the usual local alphabets, Kolezhutthu or Malayanma/Malayashma, but this text was transcribed in Garshuni Malayalam in the paper manuscripts. This situation is somewhat analogous to the double edition of the Acts of the Diamper Synod-on palm leaves in Malayashma script and on paper in Garshuni (see above, p. 262-64). If so, this testifies to a co-existence of different alphabets, used for noting the same language but in different contexts and careers. The same phenomenon also testifies to a remarkable sense of historical memory, aiming at preserving the important contemporary or recent documents for posterity. Out of this sense of preservation not only individual documents were copied in manuscripts, but entire series of letters were also copied in letter books. Particularly interesting is a Church history written in Garshuni Malayalam and preserving a letter collection, embedded in historical explanation, whose two recensions we have found in the library of Saint Joseph's Monastery of the Carmelites of Mary Immaculate in Mannanam. ${ }^{86}$

dissertations/W/JMS/001489509.pdf. The Ph.D. dissertation gives annotated textualization, translation and critical edition of another twenty percent of the corpus.

86 The manuscripts are MSS Mannanam Mal 14 and Syr 49, according to our checklist. Mal 14 is placed among the Malayalam MSS, while Syr 49 is placed among the Syriac, hence the difference in the numbering. The original shelfmarks of the MSS are: MS Mal $14-26213$ MAN M 3113; MS Syr 49 - 090-253-CAL-S. MS Syr 49 is briefly mentioned in Emmanuel Thelly: "Syriac Manuscripts in Mannanam Library," p. 268, as no. 10 among the Literary Works. 
The CMI order is an indigenous religious order founded by Blessed Kuriakos Chavara in 1831 as a result of a long struggle for independence within the Catholic fold, from the Latin hierarchy. In fact, this struggle of independence was marked by a sustained effort to hold fast to the Chaldean Syrian rite over and against the Latinized Syrian rite introduced in the wake of the Synod of Diamper, and also to the Chaldean Catholic jurisdiction over against the Padroado Latin jurisdiction of Puttenchira ${ }^{87}$ and the De Propaganda Fide jurisdiction of Varapuzha/Verapoly. ${ }^{88}$ By the second half of the nineteenth century, after the refusal of the First Vatican Council in 1869-70 to accommodate the claim of the Chaldean Catholicos Patriarch Joseph Audo to receive jurisdiction over the Malabar diocese, the Chaldean party split into two. One faction held fast to the Chaldean jurisdiction and eventually became radicalized and joined the Nestorian Church - this is the origin of the present-day Chaldean Syrian Church, with its headquarters in Thrissur, under the jurisdiction of the Church of the East and presently headed by Metropolitan Mar Aprem. The other party, headed by the Blessed Kuriakos Chavara, resigned to the status quo but continued their fight for the indigenization of the Indian Syrian Catholic community. This led finally, in 1887, to the foundation of the Syro-Malabar Church, following the cessation of the jurisdiction over the Indian Syrian Christians of the Latin bishops of Verapoly. Apparently, for the community, the history of this

${ }^{87}$ The Padroado jurisdiction is that of the bishops nominated by the Portuguese kings as a result of the Padroado (patronage) rights given to the Portuguese kings by the Popes, ratified in 1514 by Pope Leo X, including the right to nominate all the bishops of the Eastern world to be discovered. This exclusive right was silently revoked after the loss of the Portuguese maritime power, so that a new bishop was consecrated for South-Western India under the direct jurisdiction of the Congregation for the Propagation of the Faith in 1701. The traditional see of the Padroado bishops of Kerala was Kodungallur/Cranganore at the seashore, which was transferred to mainland Puttenchira after the Dutch ousted the Portuguese from Cochin in 1656. The see of the De Propaganda Fide jurisdiction was Varapuzha/Verapoly, $24 \mathrm{~km}$ north of Cochin.

88 On this, see I. Perczel, "Some New Documents on the Struggle of the Saint Thomas Christians to Maintain the Chaldaean Rite and Jurisdiction," in: Peter Bruns, Heinz Otto Luthe (eds.), Orientalia Christiana: Festschrift für Hubert Kaufhold zum 70. Geburtstag (Wiesbaden: Harrassowitz 2013), pp. 415-436. 
long struggle was very important and so they stored in their archives its documents going back to five centuries, that is, including the documents of the early encounter with and resistance against the Portuguese and their missionaries. The main body of this documentation is now divided between two manuscript and document libraries, that of the Chaldean Syrian Church in Thrissur and that of St. Joseph's CMI Monastery in Mannanam, the two sets of documents complementing each other.

So, among many other documents, the CMI library of Mannanam preserves two variants of a Church history written by the end of the $18^{\text {th }}$ century, which contains detailed documentation of the aforementioned Chaldean movement. Thus, this Church history has preserved for us, along with commentaries, the most important historical documents of the community from 1701 to 1789, mostly letters. Some sparse Syriac documents are preserved in the original Syriac, while Malayalam documents are preserved in Garshuni Malayalam. When deciphered and translated, this chronicle will prove a gold mine of the history of the Saint Thomas Christian community. The Rev. Dr. George Kurukkoor and myself have translated and commented the first part going to 1701 of this Church history, that is, its Malayalam text including a Syriac document, and intend to continue this work. ${ }^{89}$ This first part tells the history of the Malankara Church from the preaching of Saint Thomas, whose beginning it dates to $52 \mathrm{AD}$, until 1701, when Mar Shem on of Ada, an East Syrian bishop, arrived in India to meet the Chaldean community but was prevented from doing so. Instead, using his pretence that he was a (Chaldean) Catholic bishop-although his true allegiance was to Mar Eliah X Maroghin, the Nestorian Catholicos Patriarch-he was used by the Latin missionaries in India to consecrate the first Verapoly archbishop under the direct jurisdiction of the Congregation for the Propagation of the Faith, Angelo Francesco, whom no Padroado bishop would have accepted to consecrate, as this move was a violation, on the part of the Papacy, of the Padroado rights that had been conferred irrevocably upon the King of Portugal. After that,

${ }^{89}$ I. Perczel and George Kurukkoor: "A Malayalam Church History from the Eighteenth Century, based on Original Documents," in: Bibel, Byzanz und Christlicher Orient: Festschrift für Stephen Gerö zur 65. Geburtstag, ed. D. Bumazhnov, E. Grypeou, T. Sailors and A. Toepel (Leuven: Peeters, 2011), pp. 291-314. 
Mar Shem on was deported to Pondicherry, where he died in 1720, falling into a well-an event that the Syrian Christians interpreted as murder.

Interestingly, the first original documents inserted into the text of the narrative are a Syriac letter of Mar Shemen, sent to the community of the Chaldean Christians from Surath in Gujarat, where he was detained in a Capuchin monastery, and Mar Shemen's Catholic confession of faith, given to the Jesuit missionary John Ribeiro. ${ }^{90}$ This is no coincidence. The Church history was written and compiled in 1789, when Parammakkal Thomas was the administrator (Governador) of the Saint Thomas Christians. Parammakkal Thomas and his community were in open revolt against the Latin hierarchy and Mar Shemeon's mission 88 years earlier and his alleged murder 69 years earlier constituted an integral part of Parammakkal's discourse legitimating the revolt. In fact, it was item no. 1 in the accusations brought against the Verapoly archbishops and the Carmelite missionaries, Parammakkal's main enemies. ${ }^{91}$ In this, just as in all its other traits, this Church history obeys the rules of its genre: to present the history of the Church of India as a linear story of the only legitimate line of the Church, leading from the mission of Saint Thomas to the Governorship of Parammakkal Thomas. ${ }^{92}$ What is remarkable, however, and far from being a typical trait of these apologetic Church histories, is that it is supported by an entire collection of original documents, apparently copied faithfully from some archive where these documents were kept.

${ }^{90}$ Mannanam MS Syr 49, foll. 4r-6r, MS Mal 14, foll. 46r-44r. MS Mal 14 has been wrongly foliated, so that the numbering goes in the direction opposite to that of the text itself.

91 See Thomas Parammakkal's apology against the accusations brought against him by Paulinus a Sancto Bartholomaeo in the Varthamanappusthakam, Podipara, op. cit., p. 585: "Now, in times old during the days of our forefathers there came to Malabar Mar Simon, a Syrian bishop. By deceit he was made to give consecration to bishop Angelus. At midnight without the others knowing it, Mar Simon was taken to Puducherri and was killed, locked up in a room." This is of course, a distorted version of the story. For Mar Shemen's role in the justification of the revolt see also below, concerning the Angamaly Padiyola.

92 On the genre of Indian apologetic Church histories see I. Perczel, "Four apologetic Church Histories from India," The Harp 24 (2009): 189217. 
After Mar Shemeon's story, the narrative continues with the events of the episcopacy of Angelo Francesco, and of John Ribeiro, who became metropolitan bishop of Cranganore in $1703 .{ }^{93}$ The next original document inserted in the History is dated 1704 and was written in Malayalam, in Kuravilangad, by "Archdeacon Mattai, the Door of All India" to Metropolitan John ${ }^{94}$ and the series of documents continues with a number of letters by the Archdeacon. ${ }^{95}$ Archdeacon Mattai is Parambil (De Campo) Mattai, the nephew of Parambil Chandy-Alexander de Campo, the first indigenous Catholic bishop in Malabar. ${ }^{96}$ Not all the letters have a title but whenever they do, it is indicated that the text is a faithful copy, perppu, of the original. The last document in this series is by Clement XI, apparently the nomination of Angelo Francesco to be Vicar Apostolic and Metropolitan of Malankara. ${ }^{97}$

After that, the history switches to the famous travel of Kariattil Joseph and Parammakkal Thomas to Europe and the ensuing revolt of the Catholic Saint Thomas Christians against the Latin hierarchy, which is the main subject of this historical work. ${ }^{98}$ When Kariattil Joseph died on 9 September 1786, in Goa, ${ }^{99}$ the archbishop of Goa nominated Parammakkal Thomas administrator (Governador) of Kodungallur on 21 September. ${ }^{100}$ Thomas convened an assembly in Angamaly on 10 February 1787, which published a padiyola, that is,

${ }^{93}$ Mannanam MS Syr 49, fol. 7r, MS Mal 14, fol. 44r.

${ }^{94}$ Mannanam MS Syr 49, fol. 7v-8r, MS Mal 14, fol. 42r-41r.

95 Mannanam MS Syr 49, foll. 8v-16r, MS Mal 14, fol. 41r-36v.

${ }^{96}$ On this period and on Archbishop Mattai see E. R. Hambye S. J., History of Christianity in India, Vol. III: Eighteenth Century (Bangalore: The Church History Association of India, 1997), pp. 22-26 and also J. Kollaparambil, The Archdeacon of All-India (Kottayam: Catholic Bishop's House, 1972), pp. 171-175.

${ }_{97}$ Mannanam MS Syr 49, fol. 16v, MS Mal 14, fol. 36v-36r.

98 This begins in MS Syr 49, on fol. 17r. This narrative is missing from MS Mal 14.

${ }_{99}$ Hambye writes erroneously 19 September. For the correct date, see Antoney George Pattaparambil, The Failed Rebellion of Syro-Malabar Christians: A Historiographical Analysis of the Contributions of Paulinus of St. Bartholemew (Rome: A. G. Pattaparambil, 2007), p. 252, citing a letter from Archivum Generale Ordinis Carmelitarum Discalceatorum, Roma, A. Pl. 267b. What follows is based on E. R. Hambye, op. cit., p. 34-37.

100 About Joseph Kariattil and Thomas Parammakkal see in the present study, above, in section 3.4, p. 283-284. 
palm leaf document, according to which the community would not accept any foreign, Latin, bishop to rule it. The padiyola demanded that Parammakkal Thomas be nominated archbishop of Kodungallur. They declared that, failing the acceptance of this demand, they would go over to the Chaldean patriarchate and obtain a bishop from there. ${ }^{101}$ A petition with the same content was written to Queen Mary of Portugal. Not surprisingly, the next document in the Mannanam collection is this padiyola. ${ }^{102}$ This document, being the main document of the revolt of the Catholic Christians against the Latin hierarchy, retells the history of the community and, among others, invokes the deceitfulness of the Carmelites in getting Mar Shem eon of Ada to consecrate Angelo Francesco as Metropolitan and his subsequent imprisonment and murder in Pondicherry. ${ }^{103}$ After the padiyola, MS Mal 14 also contains the names of sixty-nine parishes that had joined the revolt and signed the document. ${ }^{104} \mathrm{~A}$ similar list, but only with fifty-three parishes, is found in MS Syr 49, not immediately after the padiyola but after several texts, including the copy of a royal decree issued by the Travancore raja, regulating the new situation between the revolting Christians and the Carmelite missionaries. ${ }^{105}$ In both manuscripts there comes a decision about twelve priests, dated 1787 Meedam 12, that is, the beginning of May, whose content I do not understand clearly. ${ }^{106}$ However, as far as I understand, these twelve priests are excommunicated; next, there comes a short order by the Governador Parammakkal Thomas, dated 1788 February. ${ }^{107}$ However, MS Mal 14, contains, between the

101 E. R. Hambye, op. cit., p. 34, citing a letter, dated 12 January 1788 (with a misprint writing 1778) to the Congregatio de Propaganda Fide from Archivum S. Congregationis pro Gentium Evangelizatione, seu de Propaganda Fide, Scritture riferite nei Congressi (Indie Orientali e Cina dal 1788 al 1799), vol. 39, ff. 662 r-63r.

102 Mannanam MS Syr 49 fol. 19r-20r, Mal 14, 36r-33r. For an English version of the text of the padiyola see Thomas Whitehouse, Lingering of Light in a Dark Land: Being Researches into the Past History and Present Condition of the Syrian Church of Malabar (London: William Brown and Co, 1873), Appendix D, p. 308-310.

103 Mannanam MS Syr 49, fol. 18rv.

104 Mannanam MS Mal 14, foll. 33r-31v.

105 The decree in Mannanam MS Syr 49 is on fol. 22v. The list is on fol. 23 rv.

106 Mannanam MS Syr 49 fol. 24r-25v, Mal 14, 31v-30r.

107 Mannanam MS Syr 49 fol. 25v-26r, Mal 14, 27r-26v. 
decision on the twelve priests and the order of Parammakkal, a series of other documents, missing from MS Syr 49. After another narrative part, still about the same time period, there is a metrical poem by a certain Priest Mathew (Matthu Kattanar) about the travel and death of Joseph Kariattil. Even the melody, according to which the poem is to be sung, is indicated in the title. ${ }^{108}$

After a few more documents, the documentation of Mannanam MS Mal 14 is interrupted on fol. 10r; apparently, the continuation of the text was lost. The rest of MS Syr 49 contains a rich repertory of narratives and copies of original documents, all from the eighteenth century, which would be too long and tedious to analyze here. In fact, in this manuscript, almost 150 folios (300 pages) are filled with rich documentation of the history of the century. So these two manuscripts should serve as a major source for the reconstruction of the eighteenth-century history of the community.

\section{The WRiting SyStem of THE Garshuni MaLayalam SCRIPT}

In the Appendix to the present study I have tried to give a general description of the Garshuni Malayalam writing system. As the Modern Malayalam (Arya ezbutthu) alphabet came to usage later than the Garshuni Malayalam script, namely in the $17^{\text {th }}$ century, which was a period of heavy Sanskritization of the Malayalam language, it would be improper to speak about Garshuni Malayalam transcriptions of Modern Malayalam letters. Rather, we can speak of Modern Malayalam transcriptions of the sounds also expressed in Garshuni Malayalam letters and, at least, establish equivalences between the two writing systems. Thus, in the Appendix, I give Modern Malayalam equivalents of the Garshuni letters and their combinations. As this is, as far as I know, the first attempt in the literature to give a quasicomprehensive presentation of this writing system, it cannot aim at perfection and will have to be corrected as new data, manuscripts, or a better observation of the texts will emerge. However, at this stage it is worth it to attempt such a description.

108 Mannanam MS Syr 49, fol. 29v-32r, Mal 14, 23v-21v. The melody

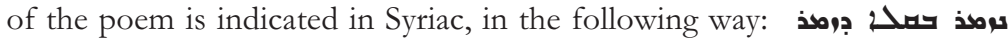
"To be sung upon the tune of the chant 'Little Boat." 


\section{CONCLUSIONS}

As I mentioned before, a few very valuable studies, the last one by Dr. Johns Abraham Konat, have been dedicated to the Garshuni Malayalam writing system and its origins. Yet, no survey of what is available in this script has been written to date. So it is such a (still quite preliminary) survey that I have attempted in the present study. I am conscious of the fact that this is just a first attempt. Yet I have tried to give a first impression of the wealth of the literature preserved in this script. I hope I can make a convincing case establishing that the manuscripts written in this script contain a treasure house of hitherto unexplored Indian Christian literature. This literature goes back at least to the sixteenth century. Often, it contains documents and literary pieces unknown from any other source, such as the Acts of Mar Abraham's Synod of Angamaly in Bangalore, Dharmaram College MS Syr 32, or the Erasmian-style polemical dialogues in Mannanam MS Syr 74, or the Church history and collection of documents in Mannanam MSS Syr 49 and Mal 14. Often, it contains documents and literary pieces known from other sources as well but in a form much closer to the original, such as the Malayalam Acts of the Synod of Diamper in Bangalore, Dharmaram College MS Syr 32, known also from manuscripts written in the Arya ezhutthu characters, or the apocryphal Acts of the Apostles in Kurukkoor MS Mal Gar 1, known also from a later palm-leaf manuscript written in the Arya ezhutthu script. The possible contribution of a future study of this literature to the factual and intellectual history of the Indian Syrian Christian community and its interaction with the West Asian and European missionaries would be invaluable.

Also, these early literary monuments provide witness to a stage of the Malayalam language, more precisely of its Syrian Christian literary dialect, which cannot be accessed otherwise. As this is a dialect with many peculiarities and also with a strong influence from Syriac, which later changed toward a more Sanskritized form, I think such a study would offer much interest for linguists. Particularly, a comparative study of the still alive Jewish Malayalam and Arabi Malayalam dialects combined with the study of thisnow extinct_-Suriyāni Malayalam dialect would be most welcome. Although whatever can be said at this stage of the research is subject to caution, I would note that the language to which these manuscripts are a witness appears to be the literary dialect of an 
elite, which also knew Syriac and easily alternated between Syriac and Suriyāni Malayalam, including Syriac citations or expressions in the Malayalam text and vice versa. The community of the script has permitted this practice.

Thus, Garshuni Malayalam is not simply a script for writing Malayalam but rather an extension of the East Syriac script, allowing for the inclusion of Malayalam and, thus, the production of mixed texts. Also, it has never been a script with strict orthography or with a limited number of characters and solutions. It used several methods to represent the phonetic wealth of the Malayalam language, based on the East Syriac pronunciation of the Syriac letters and the inclusion of old Malayalam letters into its script. It was open to evolution, tending to incorporate more Malayalam characters, this time from the new, Arya ezhutthu alphabet, as the need arose. As the West Syriac alphabet began to prevail in the second half of the nineteenth century among the Indian Syrian Orthodox community, incidentally, Garshuni Malayalam written in West Syriac characters also began to appear.

The Garshuni Malayalam script establishes yet another link, besides the Syriac literary language used in South India and the ecclesiastic community with the Syrian mother Churches, between the Indian and the West Asian Christian communities. For someone versed in Syriac this script is much more easily readable than other ancient Malayalam scripts, such as Vattezhutthu, Kolez̧utthu, or Malayalanma/Malayashma. Yet, even in Kerala, there remain only a handful of people who are still capable of reading this script which, once, had been the main instrument used by Christians to copy Malayalam texts. I feel enormously lucky that I was given the opportunity to know the Rev. Dr. George Kurukkoor, a great linguist in his own right, who taught me to read this script. It would be a worthwhile attempt to try and revive this tradition. George Kiraz, the convenor of our symposium on garshunography and the editor of the present volume, has proposed to further develop his Meltho fonts, complementing them with the specific Garshuni Malayalam characters, so that we will be able to write Garshuni Malayalam in Unicode fonts and to edit the literary and documentary texts we have in their original script. I wish very warmly that this plan might become realized. 
APPENDIX: THE GARSHUNI MALAYALAM WRITING SYSTEM

\section{A. Equivalences between Garshuni Malayalam and Modern Malayalam}

A.1. Vowels (in the table below, the consonant semkbat indicates any optional consonant)

\begin{tabular}{|c|c|c|}
\hline $\begin{array}{l}\text { Garshuni } \\
\text { Malayalam } \\
\text { letter sign }\end{array}$ & $\begin{array}{c}\text { Modern } \\
\text { Malayalam } \\
\text { equivalent }\end{array}$ & $\begin{array}{l}\text { Transcription in Latin } \\
\text { characters and notes }\end{array}$ \\
\hline$\dot{i}$ & (B⿰亻丨 & $a$ \\
\hline مَ فب & $m$ & $\begin{array}{l}\text { sa: As the vowel } a \text { is the } \\
\text { normal component of a } \\
\text { Malayalam syllable, more } \\
\text { often than not its presence is } \\
\text { indicated by an absence of } \\
\text { vowel, just like in the old } \\
\text { Malayalam and the Arya } \\
\text { ezhutthu (modern Malayalam) } \\
\text { scripts. However, } \\
\text { incidentally, the ptähā is also } \\
\text { used, mostly on the first } \\
\text { syllable. }\end{array}$ \\
\hline$\dddot{2}$ & (B) & $\bar{a}$ \\
\hline "فـ & no & $s \bar{a}$ \\
\hline 2 & ஹ, ஹற & $\begin{array}{l}i, i(\text { English } e, e e) \text { : Garshuni } \\
\text { Malayalam does not } \\
\text { distinguish between short } \\
\text { and long i. }\end{array}$ \\
\hline مب & mி, nil & $s i, s \bar{i}$ \\
\hline 2 & உ, உற & $\begin{array}{l}u, \bar{u} \text { (English } u, o o): \text { Garshuni } \\
\text { Malayalam does not } \\
\text { distinguish between short } \\
\text { and long } u \text {. }\end{array}$ \\
\hline هִ & m్ర, m్ర & $s u, s \bar{u}$ \\
\hline 2 & ()) & $\begin{array}{l}e \text { (such as } e \text { in the English } \\
\text { word bed) }\end{array}$ \\
\hline
\end{tabular}




\begin{tabular}{|c|c|c|}
\hline مب & m & se \\
\hline 2 & 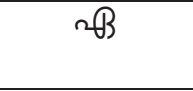 & $\begin{array}{l}\bar{e} \text { (such as } a \text { in the English } \\
\text { word blade) }\end{array}$ \\
\hline "ب & mে & $s \bar{e}$ \\
\hline$\dot{2}$ & ๑, ВЈ & $\begin{array}{l}\text { o, o: Garshuni Malayalam } \\
\text { does not distinguish } \\
\text { between short and long } 0 .\end{array}$ \\
\hline صف & ஸைग, றேை & so, sō \\
\hline "̈ & வெ) & $\begin{array}{l}\text { ay, } \bar{a} y \text { : the diphthong may be } \\
\text { short but the orthography } \\
\text { follows the standard East } \\
\text { Syriac orthography, which } \\
\text { uses the } 2 . \bar{a} p \bar{a} \text {. }\end{array}$ \\
\hline قُ & カெை & say, sāy \\
\hline$\ddot{2}$ & 39 & $a u, \bar{a} u$ \\
\hline ضُ & mY & $\begin{array}{l}\text { sau, sāu: The same holds for } \\
\text { the au diphthong as for the } \\
\text { ay. See above. }\end{array}$ \\
\hline
\end{tabular}

\section{A.2. Consonants}

\begin{tabular}{|c|c|c|}
\hline 2 & & $\begin{array}{l}\text { alap is only used for vowels. See } \\
\text { the previous table }\end{array}$ \\
\hline ב & ఎ, Ф, క & $\begin{array}{l}v a, b a, b h a: b e t h \text { is used both for } \\
\text { expressing the voiced labial stop } \\
b \text { and the labial central } \\
\text { approximant } v \text { according to the } \\
\text { two (soft and hard) } \\
\text { pronunciations of the letter beth } \\
\text { in the East Syriac dialect. } \\
\text { Garshuni Malayalam normally } \\
\text { does not distinguish aspirated } \\
\text { sounds. However, in at least one } \\
\text { manuscript, the \& (bha) letter of } \\
\text { the Arya ezhutthu script has been } \\
\text { adopted (see below, \C.2.). } \\
\text { Some manuscripts distinguish } \\
\text { between } \doteq \text { indicating the } b a\end{array}$ \\
\hline
\end{tabular}




\begin{tabular}{|c|c|c|}
\hline & & $\begin{array}{l}\text { phoneme (凹) and } \boldsymbol{Y} \text { indicating } \\
\text { the va phoneme }(\Omega) \text {. }\end{array}$ \\
\hline+ & (), 凤 & $\begin{array}{l}\text { ga, gha: a voiced velar stop, } \\
\text { corresponding to the } \\
\text { pronunciation of the Syriac } \\
\text { letter gamal. Probably, the two- } \\
\text { hard and soft_-pronunciations } \\
\text { in the East Syriac dialect of the } \\
\text { gamal permit to indicate the plain } \\
(\circlearrowleft) \text { and the aspirate (ص) } \\
\text { Malayalam sounds. }\end{array}$ \\
\hline ? & (), $\omega, \beta$ & $\begin{array}{l}\text { da, dha: a voiced dental stop. As } \\
\text { the Modern Malayalam letter tha } \\
\text { (()), originally a voiceless dental, } \\
\text { is in many cases pronounced as } \\
\text { a voiced consonant, its } \\
\text { correspondent in the Garshuni } \\
\text { script is often dālat. }\end{array}$ \\
\hline$\sigma$ & $\Omega$ & $\begin{array}{l}h a: \text { a well pronounced glottal } \\
\text { fricative. }\end{array}$ \\
\hline - & & $\begin{array}{l}\text { Waw is only used for vowels. } \\
\text { See the previous table. The } \\
\text { consonant } v \text { is expressed by beth. }\end{array}$ \\
\hline , & & $\begin{array}{l}\text { zayn has no equivalent in } \\
\text { Malayalam. It is only used in } \\
\text { Syriac loanwords or adapted } \\
\text { Syriac expressions. }{ }^{109}\end{array}$ \\
\hline س & $\Omega$ & $\begin{array}{l}\text { Heth is only used in Syriac } \\
\text { loanwords, such as Meshiha } \bar{a} \text {. In } \\
\text { such cases its pronunciation does } \\
\text { not differ from that of the } h \bar{e} \text {. }\end{array}$ \\
\hline
\end{tabular}

${ }^{109}$ For example, after the title of the metrical poem by Priest Mathew (Matthu Kattanar) about the travel and death of Kariattil Joseph in Mannanam MS Syr 49, mentioned in the Church history contained in Mannanam MS Syr 49, fol. 29v-32r, Mal 14, 23v-21v, one reads the following note on the meter and melody of the poem: عرمذ בسح "To be sung upon the tune of the chant 'Little Boat." This is, in fact, Syriac being part of the Garshuni Malayalam language, where the letter zayn naturally has a place. See main text, p. 298, n. 108. 


\begin{tabular}{|c|c|c|}
\hline$\rightarrow$ & (m) & $\begin{array}{l}\text { ta: a voiceless labial dental stop. } \\
\text { Țeth is only used in Syriac or } \\
\text { European loanwords, such as } \\
\text { Metrapōlițā, Karmelițā. }\end{array}$ \\
\hline - & 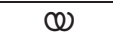 & ya: a palatal central approximant. \\
\hline 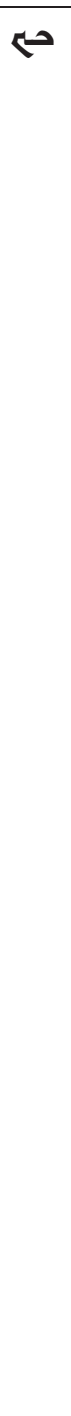 & $\begin{array}{l}\text { क, வ, } \\
\text { の, உ }\end{array}$ & 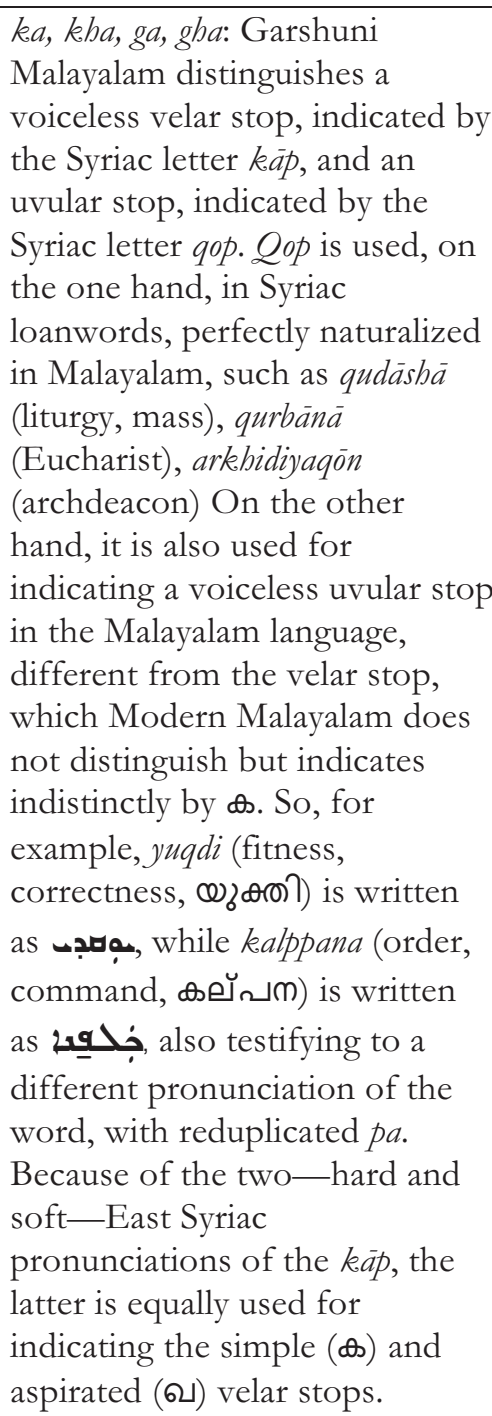 \\
\hline$\Delta$ & อ, ஜ & $\begin{array}{l}\text { la: an alveolar lateral } \\
\text { approximant, similar to our } l \text {. }\end{array}$ \\
\hline
\end{tabular}




\begin{tabular}{|c|c|c|}
\hline & & $\begin{array}{l}\text { The other is a retroflex } \\
\text { approximant, transcribed here } \\
\text { by tha, indicated by the old } \\
\text { Malayalam letter } \\
\text { below, \B.6. }\end{array}$ \\
\hline ב & ๑, ం & ma: a labial nasal. \\
\hline r & m, ח8 & $\begin{array}{l}\text { na: this is one of three } n \text { sounds } \\
\text { in Garshuni Malayalam, a dental } \\
\text { nasal. The other two are } \mathrm{Na} \text {, an } \\
\text { alveolar nasal indicated by } \\
\text { see below, } ₫ \mathrm{~B} .1 \text {-, and } \mathrm{Nha} \text {, a } \\
\text { retroflex nasal, indicated by } \\
\text { - see below, } ₫ \mathrm{~B} .2 \text {. Interestingly, } \\
\text { in Modern Malayalam, there are } \\
\text { only two } n \text { graphemes: } \mathrm{m}(\mathrm{Na}) \\
\text { indicates both the dental and the } \\
\text { alveolar nasal, while } \mathrm{m} \text {, ( } \mathrm{Nha} \text { ) } \\
\text { indicates the retroflex nasal. }\end{array}$ \\
\hline هـ & $m$ & $\begin{array}{l}\text { sa: a dental fricative. However, } \\
\text { in some cases, the same sound is } \\
\text { also expressed by șäde and taw. }\end{array}$ \\
\hline د & & 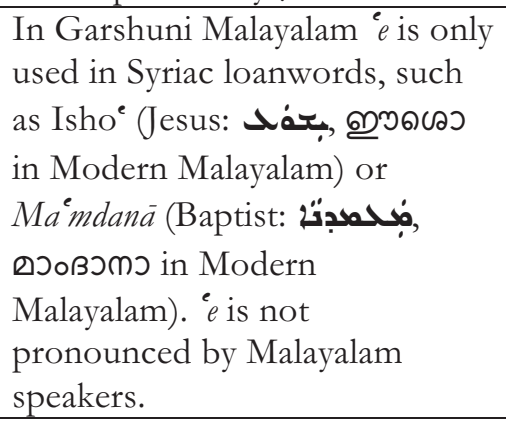 \\
\hline & مـ , & $\begin{array}{l}p a, p h a \text { : normally a labial plain } \\
\text { stop, according to the normal } \\
\text { East Syriac pronunciation of the } \\
\text { letter pe. }\end{array}$ \\
\hline 5 & $m$ & säde is not used in Garshuni \\
\hline
\end{tabular}




\begin{tabular}{|c|c|c|}
\hline & & 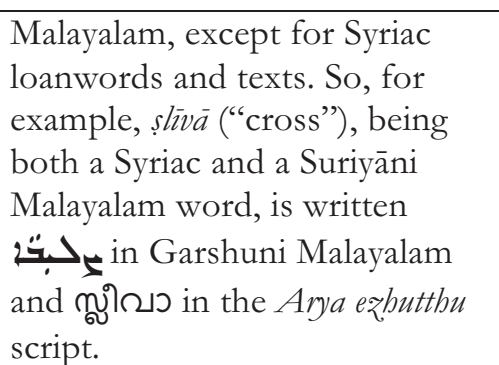 \\
\hline ע & की & $\begin{array}{l}\text { qa, a voiceless uvular stop, } \\
\text { different from ka: see above, at } \\
\text { käp. }\end{array}$ \\
\hline ذ & $\cap, \varnothing$ & $\begin{array}{l}\text { ra: a retroflex trill, pronounced } \\
\text { as Italian } r \text {. To be distinguished } \\
\text { from the alveolar trill } r b a \text { (see } \\
\text { below, } \text { B.7.). }\end{array}$ \\
\hline בַ & 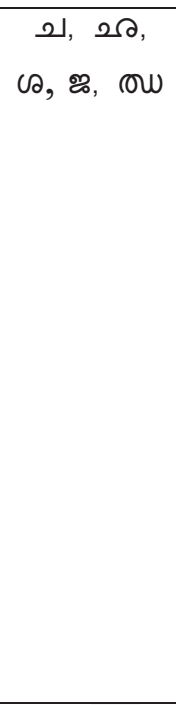 & $\begin{array}{l}c a, c h a, s h a, j a, j h a \text { : shin is used } \\
\text { for marking five different } \\
\text { sounds, being a palatal voiceless } \\
\text { stop, or fricative, distinguished } \\
\text { in Modern Malayalam. Shin is } \\
\text { also used for denoting the } \\
\text { Sanskrit sounds ja and jha. Some } \\
\text { manuscripts do not distinguish } \\
\text { between shin to be pronounced } \\
\text { as } c a \text { (a voiceless palatal stop, } \mathfrak{f} \text { ), } \\
\text { or ja, and shin pronounced as sha } \\
\text { (a voiceless palatal fricative, } \int \text { ). } \\
\text { In other manuscripts shin } \\
\text { underlined expresses the } c a \text { or } \\
\text { the ja sound, while shin without } \\
\text { the line below represents } s h a \text {. }\end{array}$ \\
\hline A & $\begin{array}{l}m, \omega, \\
\beta, \omega, \\
m\end{array}$ & $\begin{array}{l}\text { ta, tha, } d a, d h a, s a \text { : } t a(m) \text { is one } \\
\text { of the most common } \\
\text { consonants of the Malayalam } \\
\text { language, originally a voiceless } \\
\text { dental stop. At present, it is } \\
\text { pronounced voiceless (tha) at the } \\
\text { beginning of a word, but voiced } \\
(d h a) \text { if it is in the middle or at } \\
\text { the end of a word. When }\end{array}$ \\
\hline
\end{tabular}




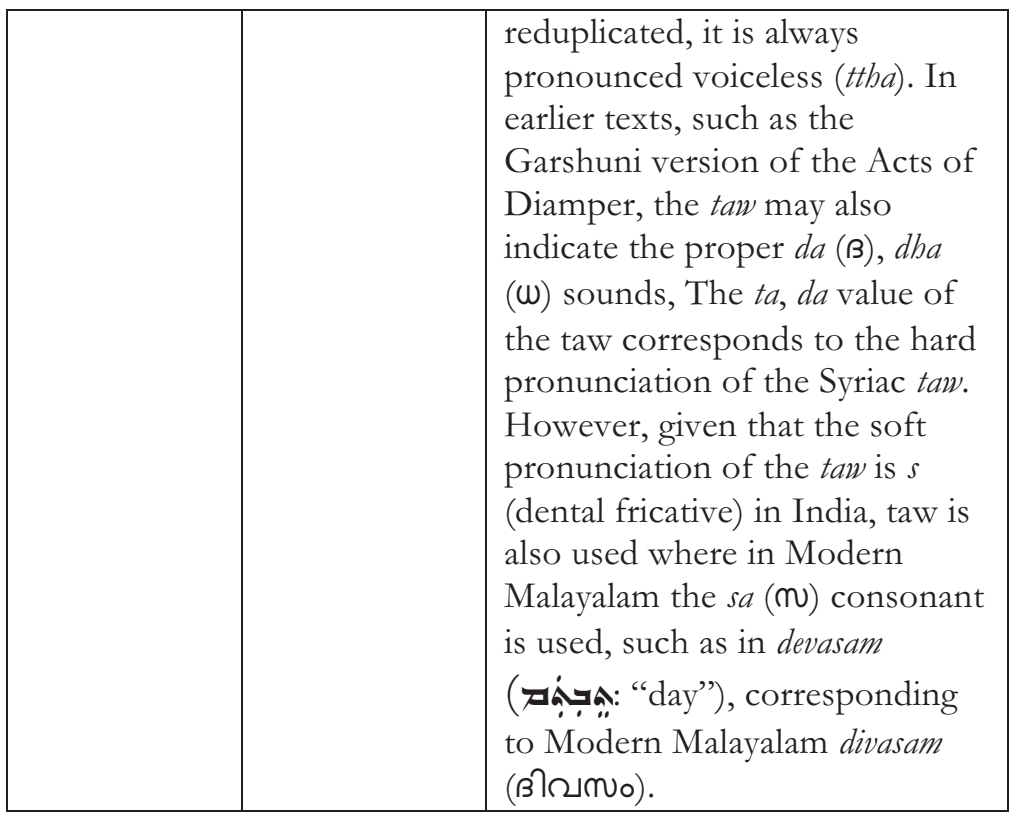

\section{B. The additional Malayalam consonants of the Garshuni Malayalam alphabet}

\section{Malayalam $\mathrm{Na}$}

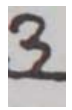

"Malayalam $N a "=$ Modern Malayalam m, $\mathrm{r}$, transcription, for the present purpose, $\mathrm{Na}$ (nun being the "Malayalam na"), pronounced like the $n$ 's in banana, but more a kind of an alveolar nasal. It connects in both directions.

\section{a. Medial position:}

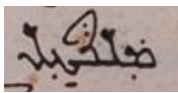

This is the word malaNáTTil, "in the mountainous region," with a medial $\mathrm{Na}$ in the middle. The fourth letter is Malayalam $\mathrm{Ta}$, reduplicated by the mbatlana in the medial position (see below, no. 5.a.). The auxiliary signs are: ptāha an the mem (Malayalam ma), 
indicating the short vowel $a$, zqāpa $\bar{a}$ in the upper compartiment of the $\mathrm{Na}$, indicating the long vowel $\bar{a}$, mbatlann $\bar{a}$ under the $\mathrm{Ta}$, indicating reduplication, hvassa under the youd, indicating the vowel $i$. The lack of a vowel sign on the first lamad indicates a short $a$, which is the basic vocalisation.

b. Initial position, including the one within the word, after a letter that does not connect to the left.

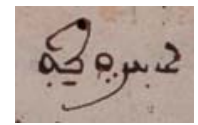

This is the word ayirbuNNu "had been." $N a$ is here in the penultimate position, before the waw, connecting only to the left. The fourth letter is a Malayalam rba connected to the right (see below, no. 7.a.). The beginning alap, having no vowel sign, is bearing the basic vowel $a$. It is followed by two yoods, the first having the value of the Malayalam consonant ya and the second,

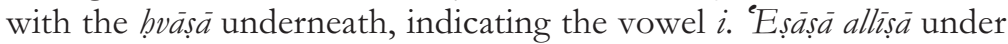
the two waw's indicates the vowel $u$, the mbatlana $\bar{a}$ line under the $\mathrm{Na}$ indicates reduplication.

c. Final position, connected to the right.

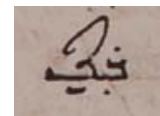

This is a final $N a$ in the word $v a N N u$ ("having gone"). One may see that beth is used for the phoneme $v$, the ptäha $\bar{a}$ is used for the vowel $a$ and the underlining (mbatlana $a$ ) means the reduplication of the phoneme. The final $u$ is, in fact, a shva.

\section{d. Final, stand alone position.}

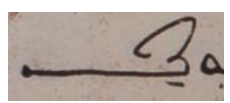

This is the grapheme for $\bar{u} N N u$ at the end of a word. This is a stand-alone $\mathrm{Na}$, with an elongated tail at the end. The line under the grapheme (mbatlana $\vec{a}$ indicates reduplication. Here is the entire word: 


\section{Con}

This is the word $m \bar{u} N N u$, "three." Here again, the final $u$ is, in fact, a shva.

2. Malayalam $\mathrm{Nba}$
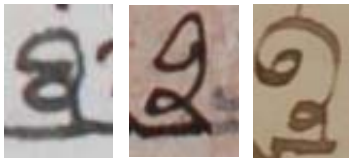

= Modern Malayalam $\mathrm{m}$, ๓ன "Malayalam

Nha," a retroflex nasal. It connects in both directions.

\section{a. Medial position:}

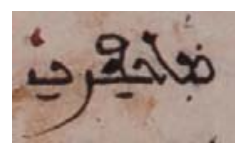

This is the word malaNbkarakku, "to Malankara," with a medial Nha at the fourth position, in the letter combination Nbka. The letter combination is indicated by the mbatlann $\bar{a}$ under the Nha, which, here, does not indicate reduplication. Another interesting feature is that the order of the two combining phonemes is reversed: first the $k a$ (Syriac käp) is written and second the Nha, while the pronunciation is aNbka. The letter in the penultimate position is a Malayalam rba connected to the right (see below, no. 7.a.) and the final ka (Syriac käp) is reduplicated by the mbatlanāa. In the same manuscript we also find the spelling Malangkara, see below, 3.a.2.

b. Initial position, including the one within the word, after a letter that does not connect to the left.

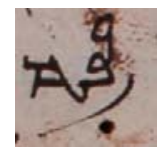

This is the word rhaNbDam, "two," with an initial Nha at the second position. The first letter is Malayalam rba in a stand-alone position (see below, no. 7.b.), the third letter is Malayalam $\mathrm{Ta}$ (see 
below, no. 5.a.) in medial position. There are no vowel signs, indicating that the appropriate consonants—rba and Ta-bear the basic vowel $a$.

c. Final position, connected to the right.

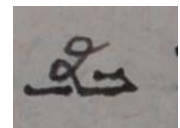

This is a final Nha in the word vaNha ("shape"?).

\section{Malayalam nga}
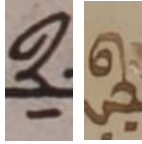

$=$ Malayalam $n g a=$ Modern Malayalam $ß$, pronunciation ya (nga), a velar nasal. It connects in both directions.

a. Medial position:

a.1.

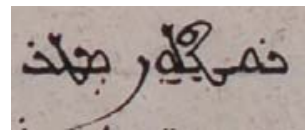

This is the word koDhanggallurh, standing for the town of Kodunggallur/Cranganore, followed by metr $<a \overline{p o}$ lita $>$. At the third position is a Malayalam $\mathrm{Ta}$ (see below, no. 5.a.), the last letter is a Malayalam $r b a$, standing alone (see below, no. 7.b.).

a.2.

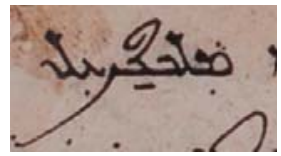

This is the word malangkarbil, "in Malankara," with a medial nga at the fourth position, in the letter combination ngk. The letter combination is indicated by the mbatlana $\bar{a}$ under the nga, which, here, does not indicate reduplication. Another interesting feature is that the order of the two combining phonemes is reversed: first the ka (Syriac kāp) is written and second the $n g a$, while the pronunciation is angka. The third letter from the end is a Malayalam rba connected 
to the right (see below, no. 7.a.). In the same manuscript we also find the spelling MalaNhkara, see above, 2.a.

b. Initial position, including the one within the word, after a letter that does not connect to the left.

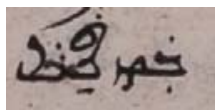

This is the word varhanggaka, "being in obedience," with an initial $n g a$ in the third position, reduplicated by the mbatlana $\bar{a}$. The first letter is Malayalam va, indicated by a beth, the second is Malayalam zha in a final position (see below, no. 8.b.).

\section{Malayalam nya}

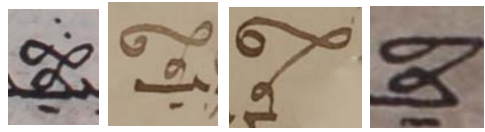

= Modern Malayalam ஸ, pronunciation ña (nya), a palatal nasal. It connects in both directions.

\section{Malayalam $T a, D a$}

a.

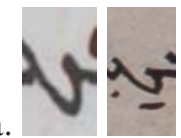

Malayalam $T a=$ Modern Malayalam $\mathrm{s}$, transcription $\mathrm{Ta}$, pronounced as a retroflex plain stop, which is voiced if it stands single $(D a)$ and is voiceless when it is reduplicated $(T T a)$. The main body of the letter is situated below the bottom line. This is the version connected both ways, that is, to the right and to the left. From the right it is connected by a horizontal line, while the left branch goes up and comes down. However, it is to be distinguished from the Syriac teth (transcription: T, see below, 5c.), which is similarly written, but with a longer left branch. In the second image, the line underneath indicates reduplication.

b. diverse connections of the letter $\mathrm{Ta}$ to the subsequent letter: 
b1.

Here $T a$ is connected to a final älap in the syllable $D \bar{e}$. It is to be distinguished from the way the têth is being connected to the following ālap. See below, 5.c.

b2.

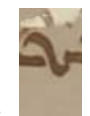

Here $T a$ is connected to a käp in the syllabic combination Daka.

b3.

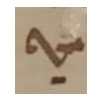

Here Ta is connected to a waw in the syllable TTu.

b4.

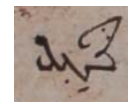

Here a reduplicated $\mathrm{Ta}$ is connected to a $\mathrm{Na}$ on the right and to a yod on the left. The pronunciation is NäTTil from the word malaNäTTil, "in the mountainous region," see above, 1.a.

b5.

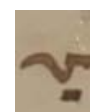

This is the final Ta. The mbatlana a indicates reduplication. Pronounciation: TTu.

b6.

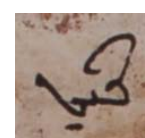

This is the syllabic combination NiTTu from meshiba piraNiTTu ("according to the year of Christ"). Here the final $\mathrm{Ta}$ is written differently from the one shown above in b5. The mbatlana $\bar{a}$ indicates reduplication.

b7.

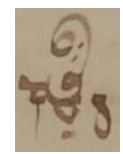


This is the word rbaNbDam (second), where one can see that the Ta is written underneath the Nha. This reproduces the composite letter $\mathrm{NbDa}$ (๓ॅs) in Modern Malayalam.

c.

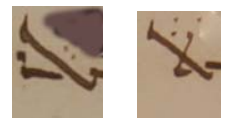

This is how the Syriac tetth $(t)$ is written in Garshuni Malayalam. This letter is only added here as a comparison to the Ta. Perhaps, its shape was influenced by the grapheme of the Ta. The têth is only used in Syriac and European loanwords. On these two images it is connected to an alap. On the first image, this is the final syllable from the word karmelita (Carmelite), on the second, from the word metropolițā

\section{Malayalam lba}

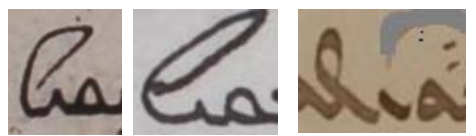

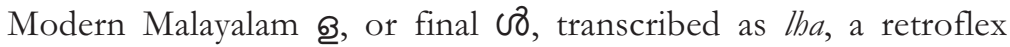
lateral approximant; normally it only connects to the right and not to the left. However, in some manuscripts, represented by picture 3 , tha is connected in both directions. On this picture it is followed by a waw.

\section{Malayalam $r b a$}

a.

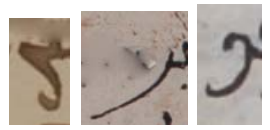

$=$ Modern Malayalam $\odot$, transcribed as $r h a$, an alveolar trill, while the Syriac resh is used to express the consonant $\cap$, a retroflex trill, such as the $r$ of the Italians. The letter rha connects only to the right, never to the left and its body is under the line; it can be written like the final nun, but with an additional curve at the end, or as an Arabic $r$, pointing leftward. 
b.

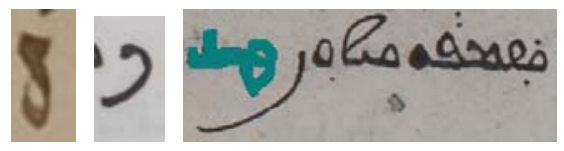

This is how the rha looks like when it is not connected in either direction. On the third picture one sees the place name Sampaulhurh (the city of Saint Paul) with a rha at the end. The lha (third letter from the left) stands alone, as it follows a waw. Noteworthy is also the diphthong au in the syllable pau, which reproduces an earlier pronunciation of a Portuguese loanword (São Paulo), close to the Portuguese pronunciation, which later changed to Sampallburh (with reduplicated $l l h a)$.

\section{Malayalam z̧ba, Sba, ja}
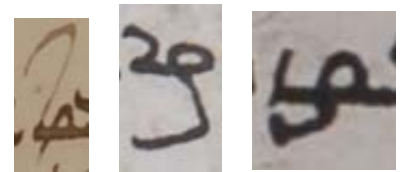

This letter stands for three different Modern Malayalam letters and sounds. Either for $\varphi$, transcription zha: a retroflex central approximant, pronounced as a sound between 1, r, and ž; or for 1 , transcription $S h a$, pronounced as a retroflex sibilant fricative (S), or for ஜ, transcription $j a$, a palatal voiced stop used mostly in Sanskrit loanwords, such as räja ("king"). However, in some later manuscripts $j a$ is indicated by the Modern Malayalam letter ஜ (see below, \C.1.). This letter only connects to the right and never to the left.

\section{Malayalam Sha, ja}

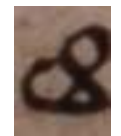

= Modern Malayalam $\mathbb{4}$, Sha, pronounced as a retroflex sibilant fricative (s), or Modern Malayalam ஜ, ja. In some manuscripts, such as Mannanam MS Syr 74, this grapheme is used in Sanskrit loanwords, such as mänuShan (man), or puruShan (man, soul, god). In the same MS other occurrences of the phoneme Sha are written 
by 7 . In Mannanam Syr 74, this letter does not connect either to the right or to the left. In this manuscript, the letter combination kSha (A) is written as a ligature of ka and zha (ص)

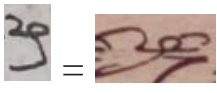
Yet, in other, quite old, manuscripts, such as Bangalore

Dharmaram College Syr 32,

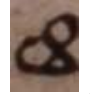
the Garshuni alphabet, which indicates both the Sha and ja sounds and connects to the right. In this MS the letter combination kSha (ब29) is written as a ligature of $\left.k a+S h a(-+8)=\mathbf{S}_{2}\right)$. This letter, which is sometimes inserted in the ductus of the script and sometimes is not, which is taken from the Arya ezhutthu script and not the old Malayalam, brings the number of the originally added Malayalam characters to nine and forms a transition toward the Modern Malayalam additions to the alphabet.

a.

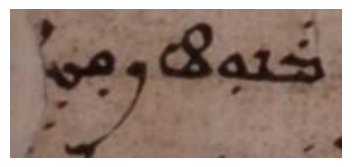

This is how the word manuSharuDe, "of men," is written in in Mannanam MS Syr 74, fol. 2r.

b.

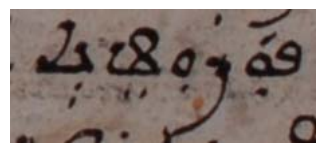

This is how the word puruShene, "a man" (accusative), is written in in Mannanam MS Syr 74, fol. 2v.

c.

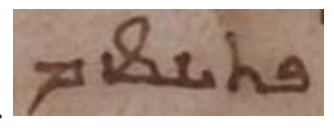

This is how the word padbinajam (according to present-day pronunciation: padbinanjam), "fifteen" is written in Bangalore Dharmaram College MS Syr 32, fol. 2r. 


\section{Additional Modern Malayalam characters or combinations, incidentally occurring in Garshuni Malayalam}

In later manuscripts, incidentally, some letters of the Modern Malayalam alphabet have also been incorporated, in order to express Malayalam sounds that were not part of the old Malayalam alphabet, nor are expressible through standard Syriac characters, that is, Sanskrit sounds. Such are the letters ஜ: $j a$ and s: $b h a$, found in a letter on foll. 515r-516r, in Ernakulam Major Archbishop's House MS Syr 7.

1. a.

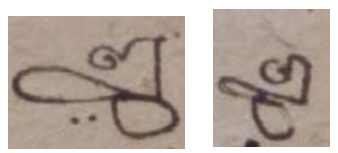

$=$ Modern Malayalam ஜ, $j a$, whose form it almost perfectly reproduces. It is pronounced as a palatal plain voiced stop, corresponding to the English $j$. The first image is from the word jenam (people) and the second, from the word ejamannanmäraru ("the leaders, lords: that is, pagan kings"). It is conspicuous that this letter, as a later borrowing from Modern Malayalam, stands as a foreign body in the script. It does not connect to any side either on the right, or the left.

b.

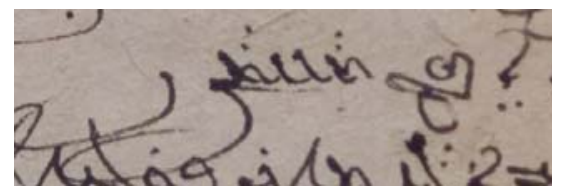

This is how the word ejamananmararu is written in the manuscript. Note that the $j a$ does not connect to any side and, also, the two allongated $r b a$ 's at the end of the word, interfering with the next line.

2.a.

= Modern Malayalam B, $b h a$, whose form it reproduces. The letter indicates a labial aspirate voiced stop. This is a unique occurrence, even in the present manuscript. The right part of the letter is cut. It 
stands at the beginning of the word combination bhagamettil kuTTi ("with the side").

b.

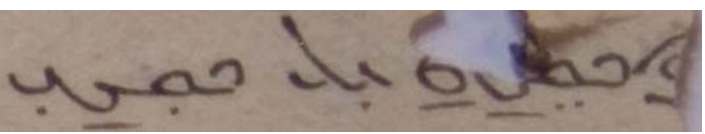

Here is the expression bhagamettil kuTTi. Note that the bha is not connected to the left-and that, certainly, it would not be connected to the right either-and also that the kapp serves both for expressing the Malayalam letters ka (க): unaspirated voiceless velar stop in kuTTi) and ga ( : unaspirated voiced velar stop in bhägam), unless here the Garshuni text reproduces an earlier or dialectal pronunciation.

3. Mannanam Syr 49, fol. 31r-32r contains a text, where the word rhäjnyi - оэ๗ஸा: "Queen," occurs several times. For this, the scribe has adopted Garshuni Malayalam rha as a stand-alone character (see above, 7.b.) with the zqāp $\bar{a}$ indicating the vocalisation of the first syllable with the long vowel $\bar{a}$, plus the single complex grapheme ஜm? used in Modern Malayalam (or, rather, its predecessor, the Arya ez̧hutthu) for jnyi:

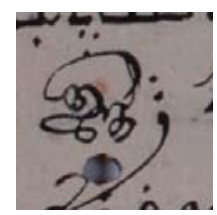

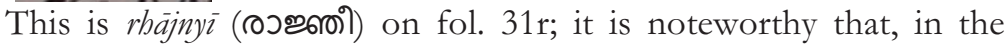
combination, the nya is not written in its Garshuni Malayalam form as

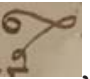
but the modern Malayalam form $\boldsymbol{m}$ is being used. Also, instead of the Garshuni way of using a yōd with a hvassā for writing the vowel $i$, it uses the connected form of the Modern Malayalam ஸற (ஸி).

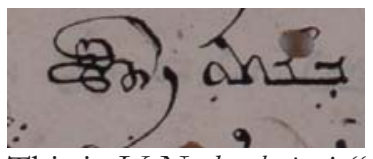

This is Vè Nadu rhäjnyi, "the Queen of Vēnad" on fol. 32r. 


\section{Letter combination, reduplication, and assimilation of consonants}

Letter combination and reduplication are indicated by the mbatlanna, written as an underscore, which here, contrary to its use in Syriac, indicates reinforcement in the pronunciation, rather than occultation. Above, in section C., several examples were given. The mbatlana $\bar{a}$ written as an upper score indicates the assimilation of consonants, incidentally-in Syro-Malayalam loanwords-the omission of a consonant (usually the he) in the pronunciation. Some of the common letter combinations, without any claim to exhaustiveness, are:

\begin{tabular}{|c|c|c|}
\hline حي & काn & ktha \\
\hline$\sqrt{3 e}$ & की & 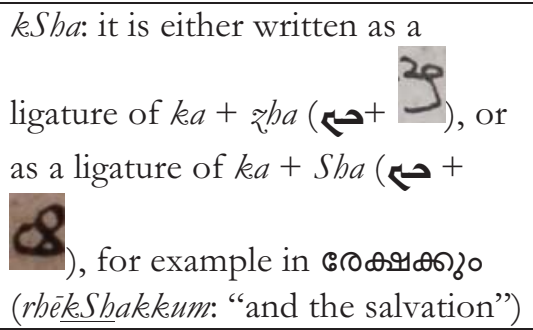 \\
\hline يַמ & ๓ัه & 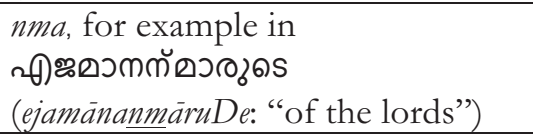 \\
\hline (9). & ๓ัs & $\begin{array}{l}\text { NhDa in rmsJo (rhaNbDäm: } \\
\text { second): it is written as a } \\
\text { combination of the Nha and the } \\
\text { Ta. }\end{array}$ \\
\hline$\frac{23}{2}$ & कs & 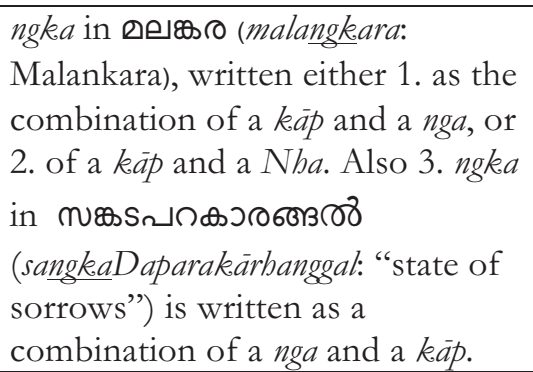 \\
\hline كمي , مي & $\mathrm{mL}$ & $m p a / m b a$ \\
\hline
\end{tabular}


Letter combinations with alteration, indicated by an upper score

\begin{tabular}{|c|c|c|}
\hline$\dot{~} \dot{\bar{\sigma}}$ & กேว & $\begin{array}{l}\text { This occurs in the Syro- } \\
\text { Malayalam word RhōmmāDé: } \\
\text { Here the assimilation of the } \\
\text { phoneme } b \text { to the } r \text { comes } \\
\text { from the Syriac. }\end{array}$ \\
\hline : & $\omega_{3}$ & $\begin{array}{l}\text { This occurs in the Syro- } \\
\text { Malayalam word } y \bar{u} d \bar{a} \\
\text { (ạo, } \mathbf{z} \text { ) "Jew." Here the } \\
\text { assimilation of the } \\
\text { phoneme } b \text { to the } y \text { comes } \\
\text { from the Syriac. }\end{array}$ \\
\hline 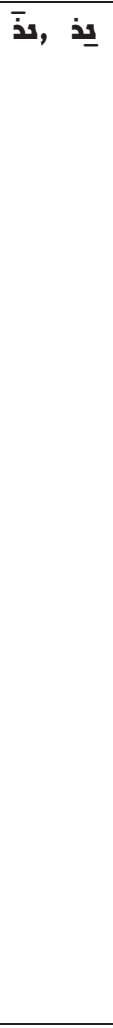 & mัn, m & 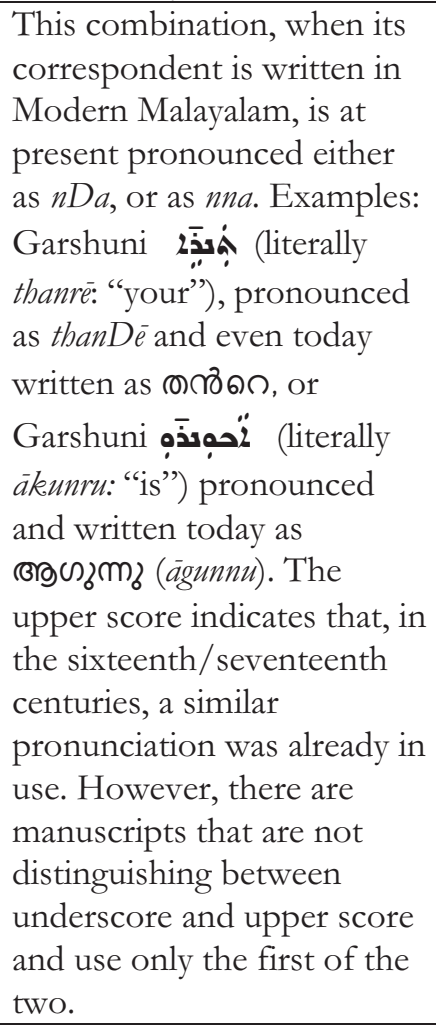 \\
\hline
\end{tabular}


